Biuletyn Historii Sztuki LXXXII:2020, nr 2

ISSN 00063967

PIOTR KNAPIK

Kraków, Uniwersytet Jagielloński

\title{
Architektura gotyckiej fary w Bochni
}

\section{Architecture of the Gothic Parish Church in Bochnia}


Architektura bocheńskiej fary jak dotąd nie cieszyła się zbyt dużym zainteresowaniem badaczy. Zazwyczaj jedynie ograniczano się do datowania i wskazywano na inspiracje czerpane z ceglanego gotyku północnego. W niniejszym tekście podjęto próbę rekonstrukcji pierwotnego wyglądu kościoła sprzed neogotyckiej przebudowy (w ramach której m.in. zmieniono kształt szczytu w fasadzie zachodniej), a także jego analizy w kontekście architektury Małopolski i Europy Środkowej. Plan budowli znajduje szereg analogii z innymi realizacjami z regionu, a także z Czech i ze Śląska. Zupełnie nietypowy dla Małopolski jest natomiast szczyt zachodni, dla którego wzór mogły stanowić późnogotyckie szczyty Gdańska lub, co bardziej prawdopodobne, Saksonii. Jak się wydaje, obecny kształt kościoła powstał w kilku fazach: od początku XV w. do ok. 2. ćwierci tegoż stulecia wzniesiono prezbiterium, a w następnych latach prawdopodobnie korpus nawowy, jednak obecna forma jego fasady zachodniej jest wynikiem odbudowy po pożarze z ok. 1485 r., której dokonano na przełomie XV i XVI wieku lub w 1. ćwierci wieku XVI.

Słowa-klucze: Bochnia, kościół św. Mikołaja, fara, architektura gotycka, gotyk

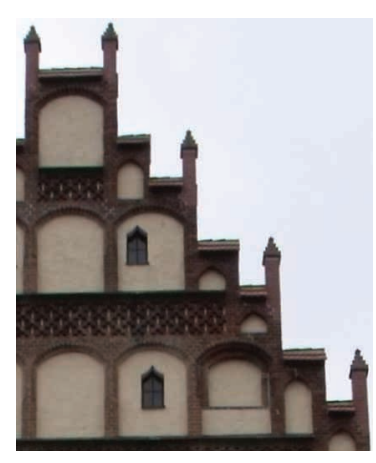

To-date the architecture of the Bochnia Parish Church has not inspired much investigative curiosity. Most generally the scholars have limited themselves to dating and pointing to brick Gothic from the North as the building's inspiration. An attempt has been made in the paper to reconstruct the genuine appearance of the Church before its Gothic Revival remodelling (which led to alterations in the western façade gable), as well as to analyse it in the perspective of the architecture of Lesser Poland and Central Europe. The plan of the building finds a number of analogies with the structures in the region, but also in Bohemia and Silesia. However, what proves utterly untypical of Lesser Poland is the western gable modelled possibly on Gdansk gables or, which is more likely, those in Saxony. It is highly probable that the current shape of the church was created in several stages: from the early $15^{\text {th }}$ century until around its second quarter the chancel was raised, with the nave body built in the subsequent years, however the current form of the Church's western façade resulted from the rebuilding after the fire in ca 1485 , conducted at the turn of the $16^{\text {th }}$ century or in the first quarter of the latter.

Key words: Bochnia, St. Nicholas Church, Parish Church, Gothic architecture, Gothic style 
$\mathrm{B}$ ochnia jako miasto górnicze w średniowieczu przeżywała apogeum rozwoju. Jedną z najważniejszych inwestycji był gotycki kościół parafialny (il. 1-3), należący do największych w Małopolsce. Literatura naukowa poświęcona jego architekturze jest jednak nadzwyczaj skromna i w większości ogranicza się do krótkich wzmianek w szerszych opracowaniach ${ }^{1}$. Powodem tego może być niewystarczająca liczba źródeł pisanych, a także późniejsze zniszczenia i przekształcenia utrudniające porównywanie $\mathrm{z}$ innymi budowlami.

Niniejszy artykuł jest pierwszą próbą monograficznego ujęcia architektury omawianego gmachu. Przede wszystkim chcę dokonać rekonstrukcji pierwotnego wyglądu budowli oraz zwrócić uwagę na prawdopodobne źródła inspiracji dla architektów, a także podjąć próbę przybliżonego określenia czasu powstania bocheńskiej fary. Jednakże już na wstępnie należy podnieść postulat przeprowadzenia wyczerpujących badań architektonicznych

Artykuł jest skróconą i przeredagowaną wersją pracy licencjackiej napisanej w roku 2018 w Instytucie Historii Sztuki UJ pod kierunkiem dr. hab. Marka Walczaka. Serdecznie dziękuję mu za pomoc, a także recenzentowi dr. Marcinowi Szymie.

${ }^{1}$ M. [Mieczysław Marasse], „Bochnia”, w: Słownik geograficzny Królestwa Polskiego i innych krajów słowiańskich, red. Filip Sulimierski, Bronisław Chlebowski, Władysław Walewski (Warszawa: Nakładem Filipa Sulimierskiego i Władysława Walewskiego, 1880), t. 1, s. 268; „Z protokołów posiedzeń Grona”, oprac. Włodzimierz DemEtrykiewicz, Stanisław KrzyżAnowski, Teka Grona Konserwatorów Galicyi Zachodniej 1 (1900), s. 366, 373, 387; Stanisław Fischer, Kazimierz Wielki i jego stosunek do Bochni i Bocheńszczyzny (Bochnia: Nakładem Tymczasowego Wydziału Powiatowego w Bochni, 1934), s. 53-54; Katalog Zabytków Sztuki w Polsce, t. 1, Województwo krakowskie, red. Jerzy SzABLowSKI, z. 2: Powiat bocheński, oprac. Józef E. DutKIEwICz (Warszawa: Ministerstwo Kultury i Sztuki, 1951), s. 1-2; Teofil WoJcIechowski, Przewodnik po Bochni (Bochnia, 1979), s. 54-57; Marian KorneCKI, „Dzieje sztuki regionu bocheńskiego", w: Bochnia. Dzieje miasta i regionu, red. Feliks KIRYк, Zygmunt RuTA (Kraków: Urząd Miasta Bochni, 1980), s. 201, 202, 206; Tadeusz Chrzanowski, Marian Kornecki, Sztuka Ziemi Krakowskiej (Kraków: Wydawnictwo Literackie, 1982), s. 89; Stanisław Wóstowicz, Kościót parafialny w Bochni i jego środowisko artystyczne. Przewodnik (Bochnia 1983); Zbigniew Beiersdorf, Bogusław Krasnowolski, Bochnia: studium historyczno-urbanistyczne, Kraków 1983-1984, t. 2, s. 16 (maszynopis w Narodowym Instytucie Dziedzictwa w Krakowie i w Urzędzie Miasta Bochnia); Jerzy Wyczesany, Wystrój artystyczny kościoła św. Mikołaja w Bochni (Bochnia: Muzeum im. Stanisława Fischera, 1988); Andrzej Olszewski, Andrzej WŁodArek, „Bochnia”, w: Architektura gotycka w Polsce, red. Teresa MroczKo, Marian ArszYŃSKi (Warszawa: Instytut Sztuki PAN, 1995), t. 2, s. 29-30 (Dzieje sztuki Polskiej, 2); Tomasz WęCŁAWowICZ, „Małopolska i ziemie ruskie Korony”, w: Architektura gotycka w Polsce, t. 1, s. 75; Jan FlaszA, Bochnia - przewodnik po mieście (Bochnia: Urząd Miejski, 2015); Andrzej WŁodareK, „The Gothic Church of the Benedectines’ Abbey at Tyniec", Biuletyn Historii Sztuki 64, nr 1-4 (2002), s. 51-52; Teofil Wouciechowski, Kościelne dzieje Bochni w czasach staropolskich (Tuchów: [s. n.], 2003); Bogusław KRASNOwoLSKI, Lokacyjne układy urbanistyczne na obszarze ziemi krakowskiej w XIII i XIV wieku (Kraków: Wydawnictwo Naukowe Akademii Pedagogicznej, 2004), cz. 2, s. 30; Jan Flasza, Bazylika św. Mikołaja w Bochni (Bochnia: Parafia pw. św. Mikołaja; Tarnów: Wydawnictwo „S-Can”, 2009); Teofil Wojciechowski, Kościelne dzieje Bochni 1772-1985 (Bochnia: s. n., 2013); Andrzej GrzYBкowski, Gotycka architektura murowana w Polsce (Warszawa: Wydawnictwo Uniwersytetu Warszawskiego, 2014), s. 179-180; Bogusław Krasnowolski, „W dobie odbudowy Królestwa Polskiego (1320-1380)”, w: Atlas historyczny miast polskich, red. Roman CZAJA, t. 5: Małopolska, red. Zdzisław NogA, z. 4: Bochnia, red. Zdzisław NogA (Toruń: Wydawnictwo Naukowe Uniwersytetu Mikołaja Kopernika, Kraków: Uniwersytet Pedagogiczny, 2016), s. 8; ID., „Rozkwit miasta: przekształcenia centrum. Rozwój przedmieść (XV w. - pierwsza połowa XVII w.)”, w: ibid., s. 9. 


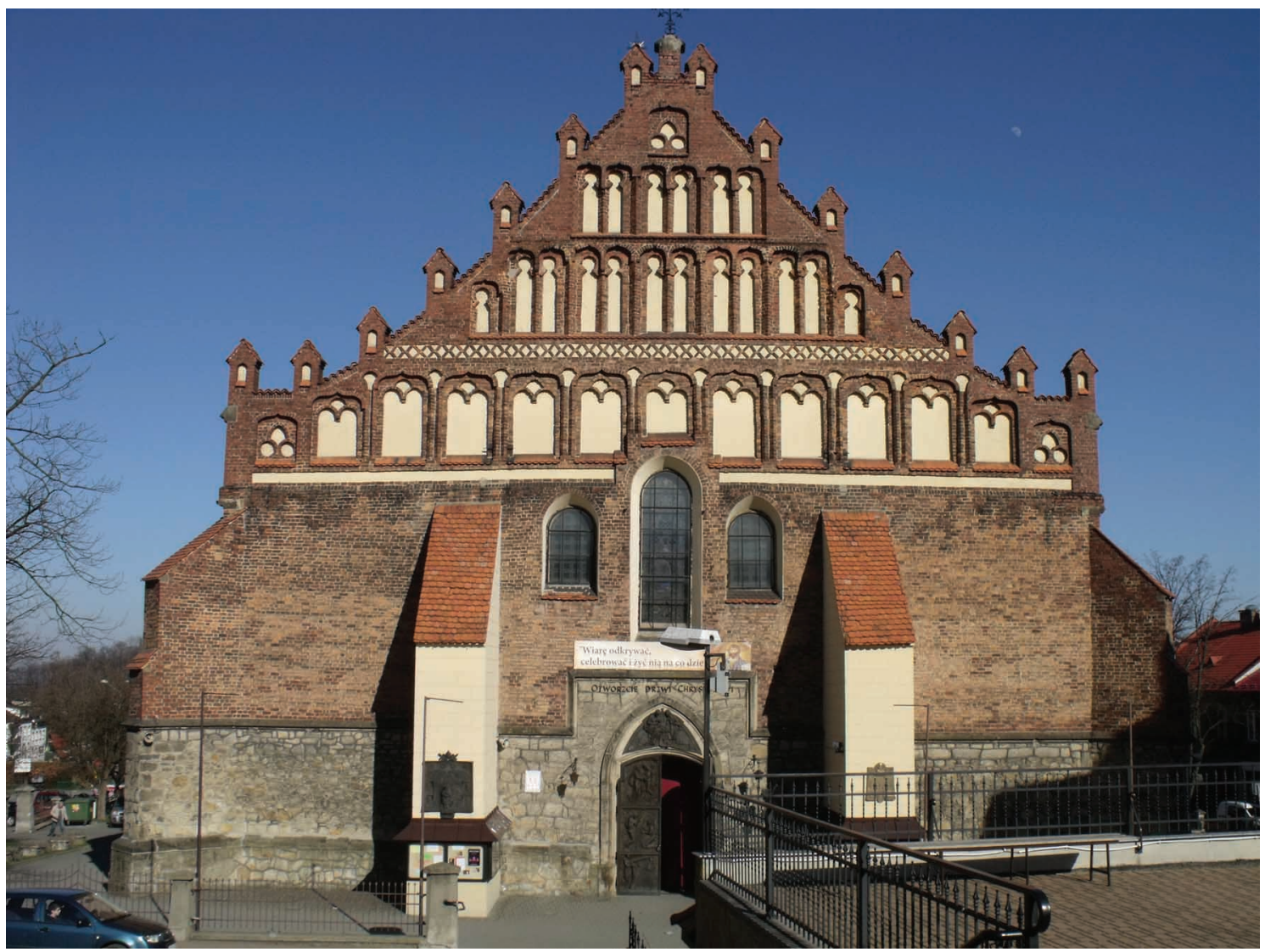

1. Bochnia, kościót św. Mikołaja, widok od zachodu. Fot. Piotr Knapik

obejmujących odkrywki struktury murów i podpór we wnętrzu, dziś całkowicie przekształconym i otynkowanym, które być może pozwolą w przyszłości doprecyzować część zaproponowanych przeze mnie tez.

Dotychczas najczęściej poruszanym zagadnieniem było datowanie fary. W najstarszej literaturze proponowano bardzo wczesny czas budowy $\left(1253^{2}\right.$, czasy Kazimierza Wielkie$\mathrm{go}^{3}$ ) lub określano go ogólnie na wiek XV $\mathrm{XV}^{4}$. Precyzyjniejszą datę przedstawił Teofil Wojciechowski, który za terminus post quem przyjął rok $1447^{5}$. Później zmienił on tę opinię, wskazując, że kościół powstał przed 1447, kiedy spłonął w pożarze, po czym został odrestaurowany do roku 1461, a następnie w 1485 r. zniszczyła go kolejna pożoga, po której odbudowano go w latach 90. XV w. ${ }^{6}$ Kolejni badacze przyjęli za początek prac wiek $\mathrm{XIV}^{7}$ lub poczatek $\mathrm{XV}^{8}$, natomiast ich koniec zadatowali na ok. $1440^{9}$. Zbigniew Beiersdorf i Bogusław Krasnowolski podjęli próbę powiązania początków budowy ze staraniami Kazimierza Wielkiego o uzyskanie odpustów dla bocheńskiej świątyni w 1353 r. ${ }^{10}$ Podkreślili

\footnotetext{
${ }^{2}$ M. M. [Mieczysław Marasse], „Bochnia”, s. 268.

${ }^{3}$ Fischer, Kazimierz Wielki i jego stosunek do Bochni i Bocheńszczyzny, s. 53-54.

${ }^{4}$ „Z protokołów posiedzeń Grona”, s. 366; Katalog Zabytków Sztuki w Polsce, s. 1-2.

${ }^{5}$ Wojciechowski, Przewodnik po Bochni, s. 54.

${ }^{6}$ WoscIEchowski, Kościelne dzieje Bochni w czasach staropolskich, s. 23-24.

${ }^{7}$ Kornecki, „Dzieje sztuki regionu bocheńskiego”, s. 201, 202; ChrZanowski, Kornecki, Sztuka Ziemi Krakowskiej, s. 89.

${ }^{8}$ Wóstowicz, Kościót parafialny w Bochni, s. 10.

${ }^{9}$ KorneCKI, „Dzieje sztuki regionu bocheńskiego”, s. 201, 202; ChrZAnowski, KorneCKi, Sztuka Ziemi Krakowskiej, s. 89; Wóstowicz, Kościót parafialny w Bochni, s. 10.

${ }^{10}$ BeIERSDOrf, Krasnowolski, Bochnia: studium historyczno-urbanistyczne, t. 2, s. 16.
} 


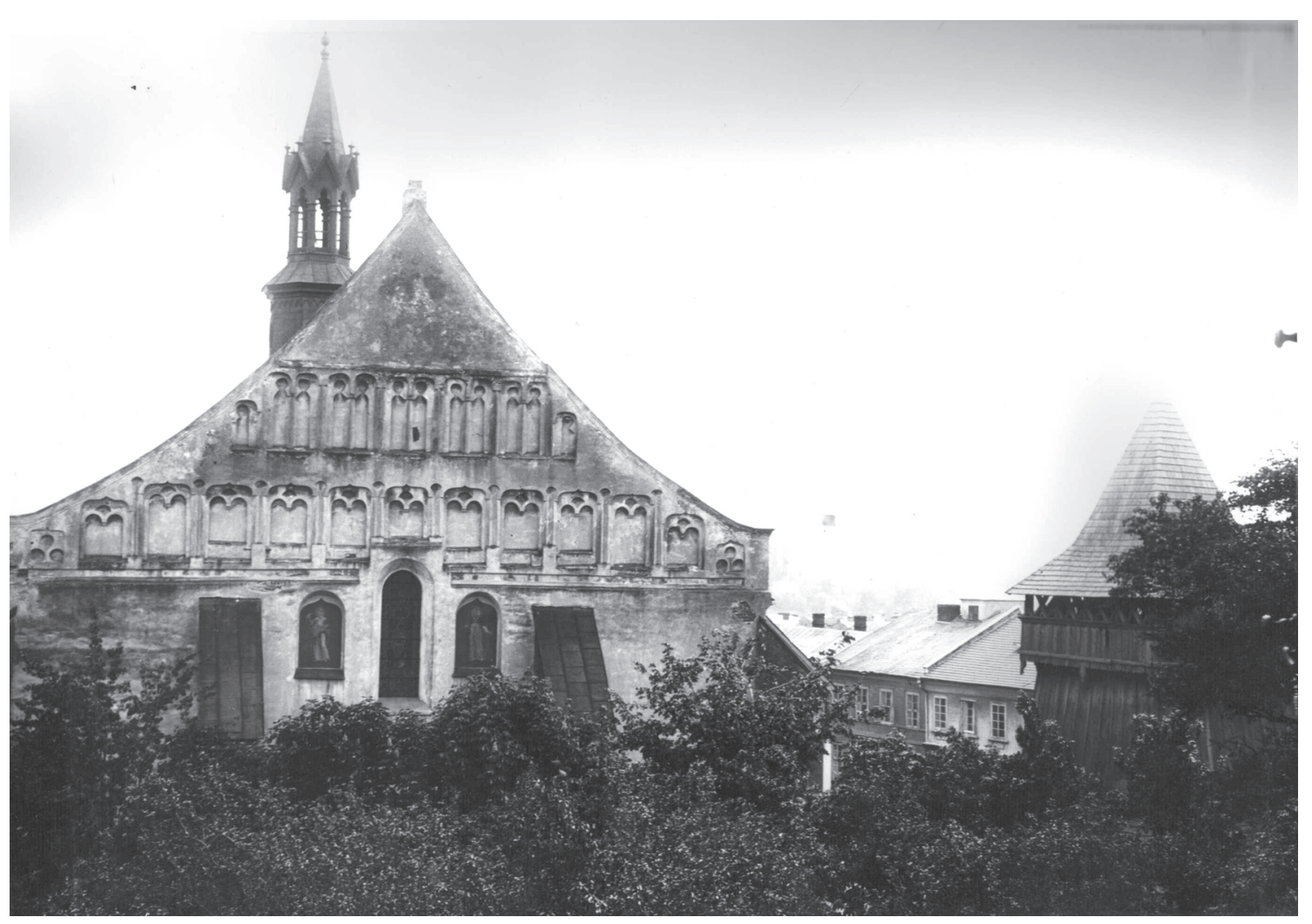

2. Bochnia, kościót św. Mikołaja, widok od zachodu. Zdjęcie archiwalne.

Fot. Włodzimierz Demetrykiewicz, Instytut Sztuki PAN w Warszawie, neg. nr 19936.

oni jednak, że kościół został następnie w XV w. przebudowany, a szczyt pochodzi dopiero z przełomu wieku XV i XVI ${ }^{11}$. Krasnowolski w kolejnych publikacjach uściślił te ustalenia, podając, że zapewne w połowie wieku XIV został ukształtowany plan i program kościoła, a obecna bryła pochodzi dopiero $\mathrm{z}$ okresu po pożarze w $1447 \mathrm{r}^{12}$ Zbliżone datowanie przyjęli także Jerzy Wyczesany ${ }^{13}$ i Jan Flasza ${ }^{14}$. Ostrożniejsi byli natomiast autorzy hasła w katalogu Architektura gotycka w Polsce, którzy bocheńską farę określili ogólnie jako pochodzącą z wieku XIV i XV, koniec prac datując na $1440 \mathrm{r}^{15}$ Teofil Wojciechowski zadatował kościół na 1. połowę XV w., zaznaczając, że ostateczny kształt uzyskał on dopiero po pożarze w roku $1485^{16}$.

Osobnym problemem jest rekonstrukcja pierwotnego wyglądu świątyni. Marian Kornecki, opierając się na informacjach ks. Stanisława Wójtowicza o odkryciach podczas konserwacji kościoła w 1960 r., stwierdził, że pierwotne sklepienie było założone wyżej i wsparte na ośmiobocznych filarach, zaś nawy rozdzielało ostrołukowe arkadowanie ${ }^{17}$. Później (wraz z Tadeuszem Chrzanowskim) podał dodatkowo informację, że średniowieczne filary zachowały się w barokowej obudowie oraz uznał, że oryginalne sklepienie

\footnotetext{
${ }^{11}$ Ibid.

${ }^{12}$ KRASNOwolski, Lokacyjne uktady urbanistyczne, cz. 2, s. 30; ID., „W dobie odbudowy Królestwa Polskiego (13201380)”, s. 8; ID., „Rozkwit miasta”, s. 9.

${ }^{13}$ WyCzesany, Wystrój artystyczny kościoła św. Mikołaja w Bochni, s. 6-7; Wyczesany twierdzi, że obecny wygląd kościoła jest efektem odbudowy po pożarze z roku 1440, a nie 1447.

${ }^{14}$ FlasZa, Bochnia - przewodnik po mieście, s. 80; ID., Bazylika św. Mikołaja w Bochni, s. 9.

${ }^{15}$ Olszewski, WŁodarek, „Bochnia”, s. 29.

${ }^{16}$ Wojciechowski, Kościelne dzieje Bochni w czasach staropolskich, s. 23-24, 32-33.

${ }^{17}$ KoRNECKI, „Dzieje sztuki regionu bocheńskiego”, s. 202.
} 


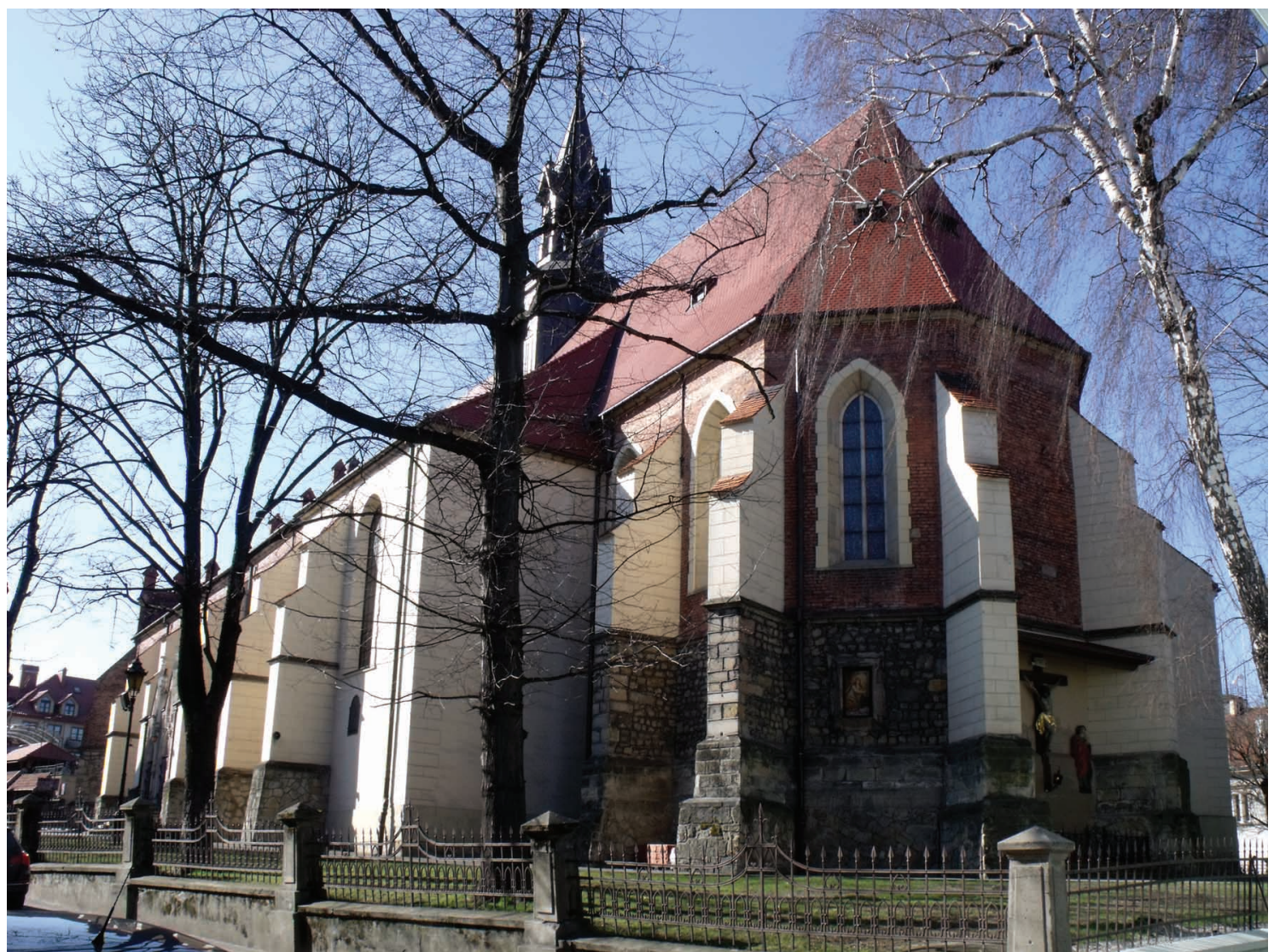

3. Bochnia, kościót św. Mikołaja, widok od strony południowo-wschodniej. Fot. Piotr Knapik

było najprawdopodobniej krzyżowe ${ }^{18}$. Sam Wójtowicz pierwotne podpory określił jednak jako sześciokątne ${ }^{19}$. Tezę o ośmiobocznych filarach i sklepieniu krzyżowym powtórzyli natomiast Wyczesany ${ }^{20}$ i Flasza ${ }^{21}$.

Wśród dotychczasowych badaczy wątpliwości nie budziła geneza artystyczna szczytu zachodniego. Zgodnie wskazywali oni na jego konotacje z północnym gotykiem ceglanym, nie precyzując jednak ich charakteru ${ }^{22}$. Podejmowano się za to prób jego oceny: Tomasz Węcławowicz określił go jako „nieporadne przetworzenie impulsów ceglanego gotyku regionów północnych"23.

Najmniejsze zainteresowanie wzbudził plan budowli. Andrzej Włodarek wskazał na podobieństwo rzutu poziomego bocheńskiej świątyni do kościołów w Proszowicach, Zatorze, karmelitów na Piasku w Krakowie i benedyktynów w Tyńcu ${ }^{24}$. Opinię tę powtórzył następnie także Andrzej Grzybkowski²5.

\footnotetext{
${ }^{18}$ ChrZAnowski, Kornecki, Sztuka Ziemi Krakowskiej, s. 89.

${ }^{19}$ Wóstowicz, Kościót parafialny w Bochni, s. 11.

${ }^{20}$ WyCzesany, Wystrój artystyczny kościoła św. Mikołaja w Bochni, s. 7.

${ }^{21}$ FLASZA, Bochnia - przewodnik po mieście, s. 80.

${ }^{22}$ KorneCKI, „Dzieje sztuki regionu bocheńskiego”, s. 202, CHrZANowsKi, KornECKI, Sztuka Ziemi Krakowskiej, s. 90; WyCZesany, Wystrój artystyczny kościoła św. Mikołaja w Bochni, s. 8; Flasza, Bochnia-przewodnik po mieście, s. 8081. Flasza jako przykład podobnego rozwiązania wskazał kościół w Wiźnie.

${ }^{23}$ WĘCŁawowicZ, „Małopolska”, s. 75.

${ }^{24}$ Zaznaczając jednak, że kościoły w Zatorze i Tyńcu miały nietypową, niewystępującą w Bochni, pojedynczą wieżę wpisaną w narożnik północno-zachodni, na podstawie której wykazał on czeską genezę ich planów; zob. WŁODAREK, „The Gothic Church of the Benedectines’ Abbey at Tyniec”, s. 52;

${ }^{25}$ GrzyBKowski, Gotycka architektura murowana w Polsce, s. 179-180.
} 
Dzieje fary ściśle powiązane są z historią samego miasta ${ }^{26}$. Kościół św. Mikołaja po raz pierwszy wspominany jest w akcie lokacyjnym Bochni z 27 lutego 1253 r., w którym mowa jest o przeznaczeniu jednego łanu frankońskiego na utrzymanie kapelana, a także o nadaniu na rzecz świątyni jednej jatki mięsnej i jednego straganu chlebowego ${ }^{27}$. Kolejny dokument, z roku 1278, wspomina o obdarowaniu solą miejscowego kapelana i określa księżną Grzymisławę jako fundatorkę kościoła ${ }^{28}$. Wzmianki z 1353 r. mówią o staraniach Kazimierza Wielkiego u papieża Innocentego VI o uzyskanie odpustów dla bocheńskiej fary $^{29}$, a zapis pochodzący z $1396 \mathrm{r}$. informuje o przeznaczeniu przez Władysława Jagiełłę dochodów z pracy jednego górnika na oświetlenie i ozdobę kaplicy Najświętszego Sakramentu oraz zatwierdzeniu przez króla wcześniejszych darowizn w tym celu ${ }^{30}$. W $1405 \mathrm{r}$. rada miasta kupiła ośmiu otroków w kopalni „,na fabrykę i erygowanie oraz utrzymanie kościoła parafialnego" 31 , do których praw krewni poprzedniego właściciela zrzekli się dopiero w roku $1436^{32}$. W 1447 r. miasto zostało zniszczone w wielkim pożarze ${ }^{33}$, brak jednak wiadomości, w jakim stopniu ucierpiała w nim fara. Murowany kościół z cegły i znajdujące się w nim ołtarze wspomina w Liber beneficiorum Jan Długosz ${ }^{34}$. W latach 1485 i 1487 miasto otrzymało przywileje królewskie celem odbudowy po kolejnym pożarze, nieznana jest jednak jego dokładna data, jak również $w$ jakim stopniu dotknął on kościół ${ }^{35}$. Z $1497 \mathrm{r}$. zachowały się wzmianki o zapisach na renowację malowideł ściennych $^{36}$. Kolejne pożogi nawiedzały miasto i farę w latach 1561, 1620, 1650 i $1655^{37}$. Szczególnie dotkliwa była ostatnia z nich, wzniecona przez wojska szwedzkie, podczas

${ }^{26}$ Ze względu na zawężony charakter niniejszej pracy, z historii kościoła przytaczam jedynie informacje niezbędne do dalszej analizy. Dzieje bocheńskiej fary są dokładnie opisane w obu pracach Teofila Wojciechowskiego.

27, ,...] ciuitatis, quam fundare et construere intendimus in loco salisfodinarum, qui polonice Bochnija, et Saltzberk Theutonice nuncupatur [...] Ad quorum eciam sustentacionem commodam et decentem sexaginta mansos Franconicos in agris cultis [...] Item pro remedio anime nostre unum mansum ad congruam sustentacionem capellani ecclesie sancti Nicolai ibid., a solucione census et decime prorsus liberum, deputamus”, ,unum tamen macellum et unam bancam panis excipimus, que predicte ecclesie beati Nicolai ab omni solucione prorsus (libera) perpetuo applicamus"; zob. Kodeks dyplomatyczny Małopolski, oprac. Franciszek PieKosiński (Kraków: Akademia Umiejętności, 1886), t. 2, nr 439, s. 8889 (Monumenta Medii Aevii Historica, 9).

28 „Iacobus capellanus noster de Bochna [...] nos humiliter spulicans, ut Sartaginem siue Patellam Salis, que per carissimam mater nostram dominam Grimislauam in fundacione Ecclesie nostre constructe in honore beati Nicolai ibidem in Bochna in dotem fuerat collata"; zob. Kodeks dyplomatyczny katedry krakowskiej ś. Wacława, oprac. Franciszek PIEKOSIŃSKi (Kraków: Akademia Umiejętności, 1874), cz. 1, nr 80, s. 106 (Monumenta Medii Aevii Historica, 1).

${ }^{29}$ Analecta Vaticana 1202-1366, oprac. Jan PTAŚNIK (Cracoviae: Sumpt. Academiae Litterarum Cracoviensis, 1914), s. 342 (Monumenta Poloniae Vaticana, 3).

30 ,Średniowieczne przyczynki źródłowe do dziejów bractwa literackiego Najświętszej Maryi Panny w Bochni i do salin bocheńskich”, oprac. Bolesław Kumor, Archiwa, Biblioteki i Muzea Kościelne 1, nr 5 (1960), z. 2, s. 183.

${ }^{31}$ Zbiór dokumentów małopolskich, cz. 5: Dokumenty z lat 1401-1440, oprac. Irena SuŁKOwSKA-KuRAś, Stanisław KuRAŚ (Wrocław-Warszawa-Kraków: Ossolineum, 1970), nr 1179, s. 38; „Średniowieczne przyczynki źródłowe”, nr 7, s. 192: „pro fabrica et eretione ac sustentacione ecclesiae parochialis sancti Nicolai”.

32 „Średniowieczne przyczynki źródłowe”, nr 8, s. 194.

33 „Spominki bocheńskie”, oprac. Stanisław LuKas, w: Monumenta Poloniae Historica (Lwów: W Komisie księgarni Gubrynowicza i Schmidta, 1878), t. 3, s. 245: ,anno domini 1447 Bochnya exarsit et est exusta per ignem in nocte post festum Egidii".

${ }^{34}$ Jan DŁugosz, Liber beneficiorum dioecesis cracoviensis, red. Aleksander PrZEZDZIECKI (Cracoviae: Ex typographia Kirchmajeriana, 1864), t. 2, s. 126 (Joannis Dlugossi opera omnia, 8).

${ }^{35}$ Wojciechowski, Kościelne dzieje Bochni w czasach staropolskich, s. 24.

${ }^{36}$ Ibid., s. 26.

${ }^{37}$ Stanisław FischeR, „Pożary w dawnej Bochni”, w: Księga pamiatkowa na jubileusz 60-cio lecia Towarzystwa Ochotniczej Straży Pożarnej Król. Górn. m. Bochni, red. Stanisław CzYżEwıcz (Bochnia: Tow. Ochot. Straży Pożarnej miasta Bochni, 1930), s. 26-29; WojcIECHOwsKi, Kościelne dzieje Bochni w czasach staropolskich, s. 25. 
której zawaliły się sklepienia fary ${ }^{38}$. W roku 1664 wizytator parafii odnotował trwający remont świątyni ${ }^{39}$. Pożar w 1756 r. zniszczył część dachu ${ }^{40}$. W następnych latach przebudowano kaplicę południową w celu umieszczenia w niej obrazu Matki Boskiej Bocheńskiej (1777-1778) ${ }^{41}$, a także wykonano szereg remontów: dachu w latach 1799-1807 (wraz z wymianą szyb w oknach) ${ }^{42}$ i $1828^{43}$, fundamentów, murów zewnętrznych, filarów i okien w $1833^{44}$, a także ponownie dachu w 1854 r. (wówczas wybudowano także nową sygnaturkę $)^{45}$. Niejednokrotnie dokonywano także rozmaitych rozbudów: w latach 1804 i 1806 przed północnym i południowym wejściem dodano drewniane kruchty ${ }^{46}$, które w 1846 r. zastapiono murowanymi ${ }^{47}$, w $1858 \mathrm{r}$. skarbiec powiększono o dodatkowe piętro połączone schodami z zakrystią ${ }^{48}$. W $1891 \mathrm{r}$. Włodzimierz Demetrykiewicz odnotował, że kościół, choć mocno przebudowany w okresie baroku, wciąż miał kamienne późnogotyckie obramienie głównych drzwi wejściowych (samo wejście było zamknięte łukiem okrągłym) oraz gotyckie sklepienie krzyżowe w kaplicy na zakończeniu nawy północnej49. Kaplicę tę z okazji sześćsetnej rocznicy śmierci bł. Kingi wyremontowano i regotyzowano w latach 1892-1893 według projektu Tadeusza Stryjeńskiego konsultowanego przez Jana Matejkę (który m.in. zalecił wykonanie w oknie maswerku i zaprojektował polichromię) $)^{50}$. W latach 1901-1906 dokonano wielkiej restauracji i regotyzacji całego kościoła, w ramach której przebudowano fasadę według projektu Jana Sas Zubrzyckiego, wybudowano nowe neogotyckie kruchty, wykonano laskowania w otworach okiennych, a w licu murów wymieniono szereg zniszczonych kamieni, cegieł, spoin i gzymsów ${ }^{51}$. Ponadto częściowo otynkowano budynek, osuszono fundamenty i wymieniono pokrycie dachu, jak również rozebrano i wymurowano na nowo jedną ze zniszczonych przypór w ścianie północnej ${ }^{52}$. Dopełnieniem renowacji było wykonanie w 1912 r. nowej polichromii oraz wymiana posadzki ${ }^{53}$. Kolejny kompleksowy remont, konieczny przede wszystkim ze względu na szkody górnicze, przeprowadzono w latach 1960-1967. Wzmocniono i osu-

\footnotetext{
${ }^{38}$ Wóstowicz Kościół parafialny w Bochni, s. 11; FLASZA, Bochnia-przewodnik po mieście, s. 81; według Wojciechowskiego w wizytacji z roku 1618 jest mowa o drewnianym stropie - na tej podstawie twierdzi on, że sklepienia zawaliły się już w czasie pożaru w roku 1561; zob. WoJcIECHOwski, Kościelne dzieje Bochni w czasach staropolskich, s. 27; jednak, jak mi się wydaje, w wizytacji jest mowa raczej o dachu krytym gontem (tectum).

${ }^{39}$ Wojciechowski, Kościelne dzieje Bochni w czasach staropolskich, s. 27.

${ }^{40}$ FisChER, „Pożary w dawnej Bochni”, s. 29.

${ }^{41}$ Stanisław Fischer, Matka Boska Bocheńska i jej kult (Bochnia: W. Hillenbrand, 1934), s. 118, WoJciechowsKi, Kościelne dzieje Bochni w czasach staropolskich, s. 27.

42 Wojciechowski, Kościelne dzieje Bochni 1772-1985, s. 66.

${ }^{43}$ Ibid., s. 67.

${ }^{44}$ Ibid., s. 67-68.

45 Ibid., s. 68-69.

${ }^{46}$ Ibid., s. 66-67.

${ }^{47}$ Ibid., s. 68.

48 Ibid., s. 70 .

49 „Z protokołów posiedzeń Grona”, s. 366; według Teofila Wojciechowskiego w latach 1731-1773 nad nawą północną wybudowano chór dla mansjonarzy, przy okazji czego wybudowano w niej nowe, niższe barokowe sklepienie, a obecne jest neogotyckie z końca XIX w., autor nie podał jednak do tej informacji żadnych przypisów; zob. WoJCIECHOWSKI, Kościelne dzieje Bochni w czasach staropolskich, s. 27. Informacja ta wydaje się błędna, tym bardziej że w przypadku ewentualnej wymiany sklepień na kolebkowe i obniżenia wnętrza zniszczone zostałoby znajdujące się w kaplicy gotyckie malowidło.

${ }^{50}$ „Z protokołów posiedzeń Grona”, s. 373, 387; Wojciechowski, Kościelne dzieje Bochni 1772-1985, s. 74, 85.

${ }^{51}$ Wojciechowski, Kościelne dzieje Bochni 1772-1985, s. 75-78.

52 Ibid., s. 76-78.

${ }^{53}$ Ibid., s. 86-90.
} 


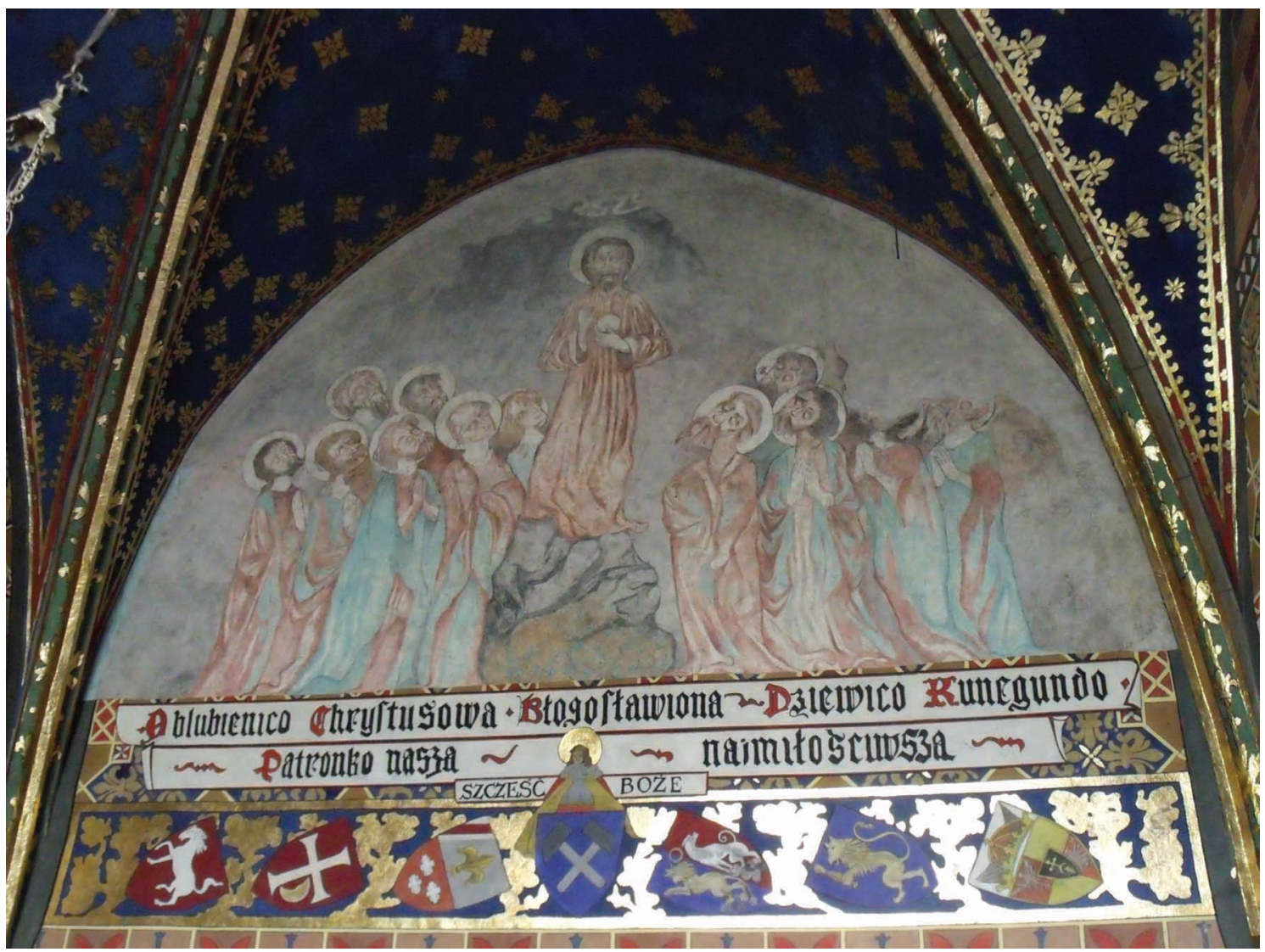

4. Bochnia, kościót św. Mikołaja, gotyckie malowidło w kaplicy św. Kingi. Fot. Piotr Knapik

szono fundamenty, wykonano stalowe ściagi poniżej posadzki i ponad sklepieniami, a same sklepienia częściowo przemurowano ${ }^{54}$. Dodatkowo wykonano nową przyporę dla podparcia kaplicy Matki Boskiej, wymieniono tynki, zrekonstruowano gzyms wieńczący w prezbiterium i częściowo wyremontowano dach. We wnętrzach wymieniono posadzkę w kaplicy Matki Boskiej, wybudowano nowy chórek muzyczny w nawie głównej, a w latach 1965-1970 wykonano nową polichromię, zachowując i konserwując starą w kaplicy św. Kingi. W 1966 r. odkryto gotyckie malowidło przedstawiające Rozesłanie Apostołów ${ }^{55}$. Kolejną konserwację tej kaplicy przeprowadzono w roku 2000. Odtworzono wówczas wspomniane malowidło, wcześniej bardzo zniszczone ${ }^{56}$. Ostatnie remonty przeprowadzone zostały w latach 2008-2009 (wymiana więźby dachowej i dachówki), oraz w 2014 r. (położenie marmurowej posadzki w korpusie nawowym kościoła) ${ }^{57}$, a od 2018 r. stopniowo są remontowane elewacje zewnętrzne.

Źródeł ikonograficznych dokumentujących stan sprzed neogotyckiej przebudowy zachowało się niewiele. Najstarszym przedstawieniem jest pochodzący z końca XVII w. obraz z serii Cuda bł. Kingi znajdujący się w klasztorze klarysek w Starym Sączu ${ }^{58}$. Ukazano na

\footnotetext{
${ }^{54}$ Ibid., s. 80-84; Wóstowicz, Kościót parafialny w Bochni, s. 15-16.

${ }^{55}$ Wojciechowski, Kościelne dzieje Bochni 1772-1985, s. 94-95.

${ }^{56}$ WojciechowsKi, Kościelne dzieje Bochni w czasach staropolskich, s. 26 (przypis 64).

${ }^{57}$ Flasza, Bochnia - przewodnik po mieście, s. 84.

${ }^{58}$ Marian KorneCKI, „Błogosławiona Kinga - pamiątki, obiekty kultu, dzieła sztuki. Inwentarz z terenu diecezji tarnowskiej”, Currenda 140, nr 1-3 (1990), s. 94, 102; Jan Flasza, „Swięta Kinga i Bochnia”, Tarnowskie Studia Teologiczne 18 (1999), s. 207; ID., „Jak pokazać dzieje Bochni w obrazach”, Kronika Bocheńska 22, nr 3 (2014), s. 28-29; ID., „Dawne plany i widoki”, w: Atlas historyczny miast polskich, s. 14.
} 


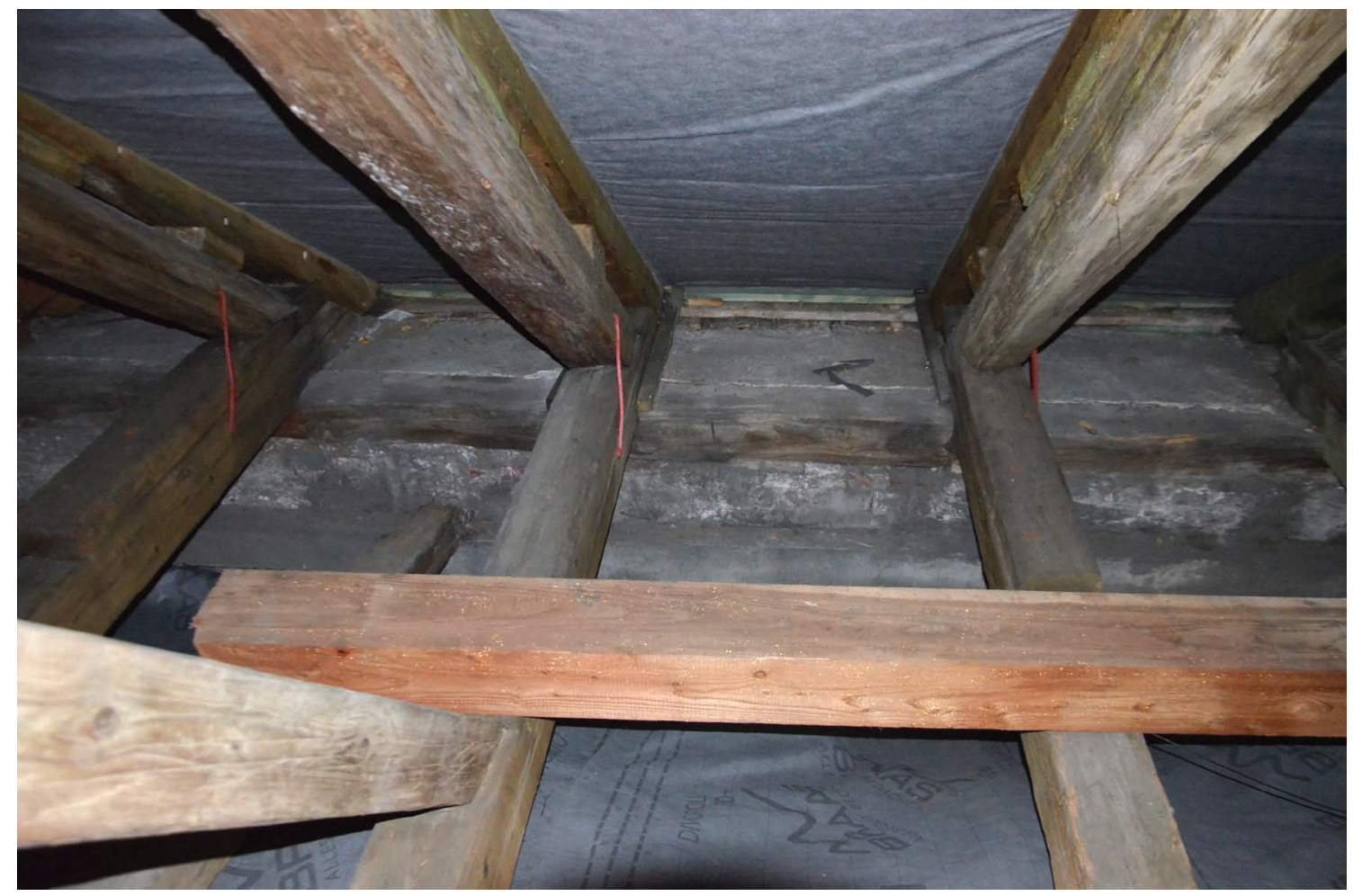

5. Bochnia, kościót św. Mikołaja, strych nad nawa pótnocnq. Fot. Piotr Pajor

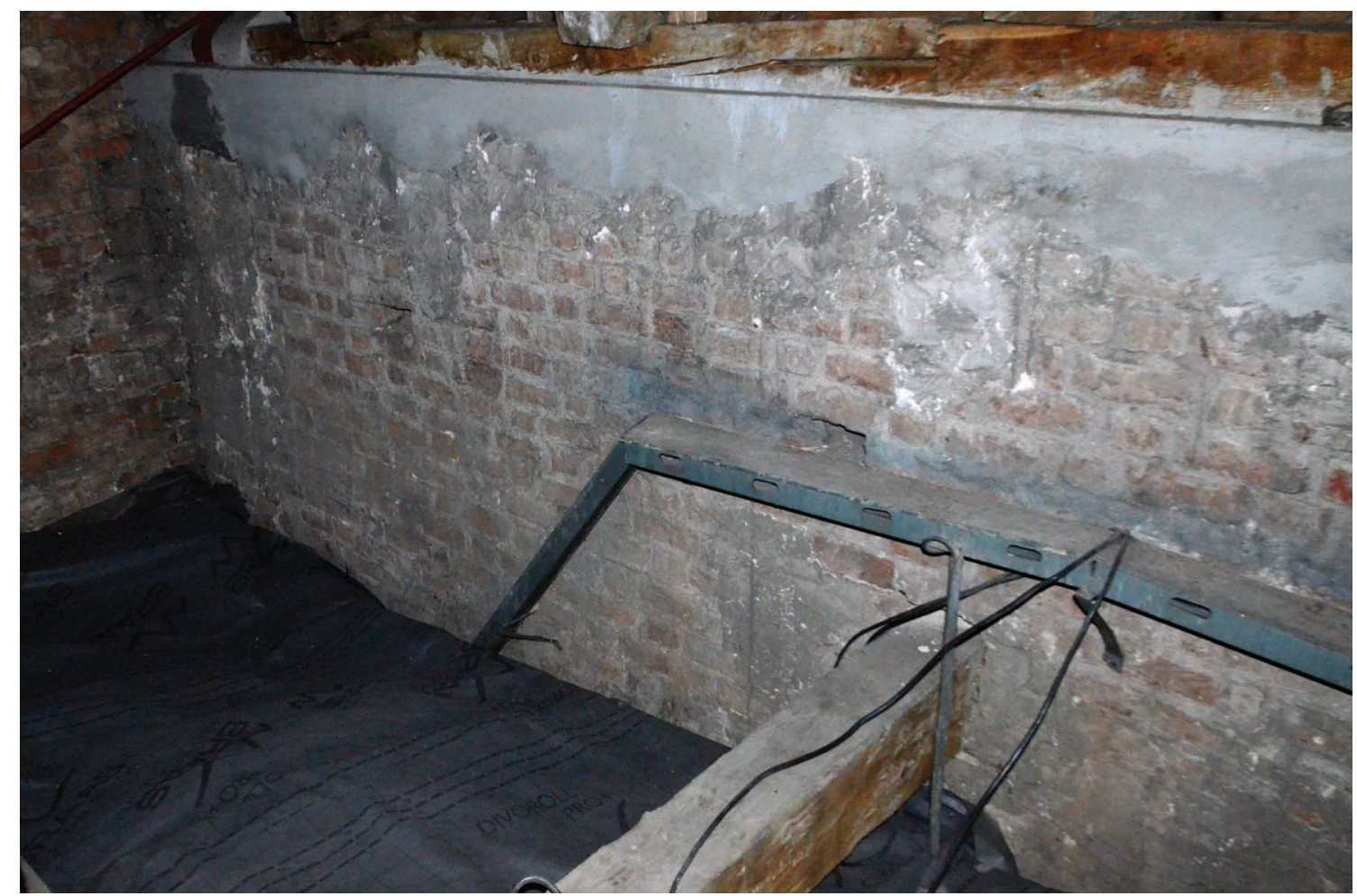

6. Bochnia, kościót św. Mikołaja, strych nad nawa południowa, fragment muru ponad arkadowaniem międzynawowym. Fot. Piotr Pajor 


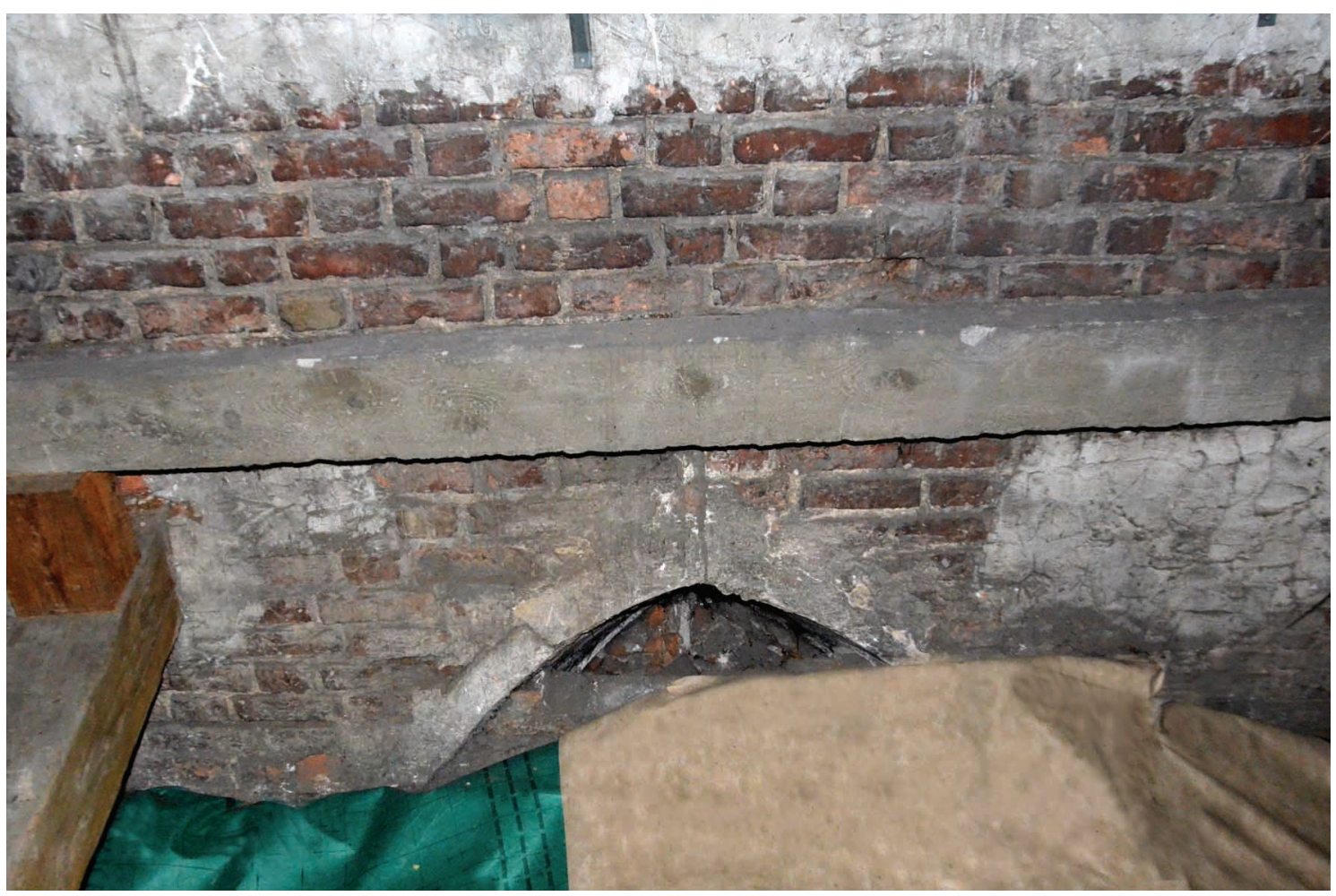

7. Bochnia, kościót św. Mikołaja, strych nad kaplica Mariacka, relikt okna w prezbiterium. Fot. Piotr Pajor

nim ugaszenie przez nią pożaru żupy bocheńskiej na tle panoramy miasta wraz z kościołem. Kolejne widoki Bochni pochodzą już z XIX w. i są to drzeworyt z $1838^{59}$ oraz litografia Carla Bernda z $1846 \mathrm{r} .{ }^{60}$ Nieco późniejsze są pierwsze przedstawienia samej fary rycina z połowy XIX w. ${ }^{61}$, akwarela datowana na 2 . połowę XIX stulecia ${ }^{62}$ i dość szkicowy rysunek Jana Matejki ${ }^{63}$. Wszystkie one są jednak na tyle schematyczne, że praktycznie uniemożliwiają wyciągnięcie jakichkolwiek szczegółowych wniosków. Wyjątek stanowi jedynie zdjęcie wykonane przez Demetrykiewicza ${ }^{64}$ (il. 2), na którym wyraźnie widoczny jest fragment fasady zachodniej (w dalszej części pracy posłuży ono do rekonstrukcji pierwotnego wyglądu szczytu).

Bocheńska fara znajduje się przy placu Świętej Kingi, w pobliżu północno-zachodniego narożnika rynku, od którego oddziela go pas zabudowy. Od innych małopolskich kościołów wyróżnia ją wykonanie ścian z dwóch materiałów: dzikiego kamienia (do połowy wysokości) i cegły w wątku gotyckim (powyżej). Ponadto z ciosu kamiennego odkute zostały glify wnęk okiennych w prezbiterium i gzymsy. Jest to orientowana, trójnawowa, czteroprzęsłowa budowla w typie pseudobazyliki z długim, także czteroprzęsłowym, trójbocznie

\footnotetext{
${ }^{59}$ Muzeum im. Stanisława Fischera w Bochni, sygn. MB-AH/2414.

${ }^{60}$ Muzeum im. Stanisława Fischera w Bochni, sygn. MB-AH/2413.

${ }^{61}$ Repr. BeIERSDORF, Krasnowolski, Bochnia: studium historyczno-urbanistyczne, t. 3, il. 170; Wojciechowski, Kościelne dzieje Bochni w czasach staropolskich, s. 397.

${ }^{62}$ Muzeum Narodowe w Krakowie, oddział Muzeum im. Emeryka Hutten-Czapskiego, sygn. NI 4875; repr. BeIERSDORF, KRASNOWOLSKI, Bochnia: studium historyczno-urbanistyczne, t. 3, il. 82.

${ }^{63}$ Muzeum Narodowe w Krakowie, oddział Dom Matejki, nr inw. MNK IX-347.

${ }^{64}$ Negatyw w IS PAN w Warszawie, nr 19936; repr. BeIERSDORF, KRASNOwolski, Bochnia: studium historyczno-urbanistyczne, t. 3, il. 169.
} 
zamkniętym prezbiterium (il. 3). Od strony północnej do chóru przylega jednoprzęsłowa kaplica św. Kingi, znajdująca się na przedłużeniu nawy bocznej, oraz dwuprzęsłowa, piętrowa zakrystia o ściętym narożniku północno-wschodnim. Późniejszymi dobudowami są pomieszczenie pomiędzy przyporami w narożniku zakrystii i prezbiterium, kaplica na przedłużeniu nawy południowej i neogotyckie kruchty przy ścianach bocznych korpusu.

Wnętrze jest niemal w całości barokowe. Wyjątek stanowi kaplica św. Kingi, niższa od naw, z prostymi, pozbawionymi artykulacji ścianami oraz sklepieniem krzyżowo-żebrowym o wklęsłych profilach żeber i zwornikiem z motywem sześcioramiennej gwiazdy. Na osi jej północnej ściany znajduje się ostrołukowo zamknięte okno z neogotyckim maswerkiem, na ścianie południowej w lunecie gotyckie malowidło przedstawiające Rozesłanie Apostołów (il. 4).

Kościół z zewnątrz jest opięty jednouskokowymi, otynkowanymi (w prezbiterium jedynie częściowo) przyporami, między którymi znajdują się ostrołukowe zamknięte okna otoczone tynkowanym obramieniem. Jak już wspomniano, elewacje są dwustrefowe: z dzikiego kamienia i cegły w wątku gotyckim, przedzielone ciosowym gzymsem kapnikowym przebiegającym na wysokości parapetów okiennych. Częściowe przelicowania cegieł są widoczne w wielu miejscach, szczególnie rzuca się w oczy wykonana z cegły maszynowej partia murów pod gzymsem koronującym.

Fasada zachodnia (il. 1) ma narożne, ukośne, nietynkowane przypory, a także dwie przypory poprzeczne, które wyjątkowo nie mają uskoków i zostały otynkowane. Pomiędzy nimi znajduje się zamknięty ostrym łukiem otwór wejściowy z kamiennym obramieniem. Ponieważ gzyms kapnikowy załamuje się tym miejscu, aby go ominąć także dolna, kamienna strefa sięga nad portalem nieco wyżej. Nad nim znajdują się trzy ostrołukowo zamknięte wnęki okienne, przy czym strzałka ich łuków jest bardzo niewielka. Środkowy otwór jest większy od bocznych i od dołu sięga niemal do gzymsu kapnikowego, zaś od góry wcina się w szczyt. Okna wprawione w omawiane otwory zamknięte są łukiem pełnym i nie mają podziałów za pomocą ciosowych lasek.

Szczyt zamykający fasadę ma trójkątny kształt ze sterczynami w formie niewielkich kapliczek z płycinami. Został on podzielony na trzy horyzontalne strefy z blendami zamkniętymi łukami w ośli grzbiet, w które wpisano dodatkowe, mniejsze płyciny tynkowane na biało. W dolnej strefie mają one dekoracyjne zamknięcia składające się z podwójnych łuków pełnych, które połączone zostały powyżej trzecim łukiem. Wyjątek stanowią jedynie skrajne blendy, w które zamiast tego wpisano trójlistne rozetki. Ponadto w strefie tej większe blendy połączone zostały ze sobą dodatkowymi, niewielkimi łukami, wydzielającymi małe tynkowane pola. Powyżej znajduje się fryz rombowy oddzielający pierwszą strefę szczytu od drugiej. W drugiej i trzeciej strefie większe blendy są węższe i zestawione parami, tak, że szerokość pary odpowiada szerokości blendy w strefie pierwszej. Wpisane w nie mniejsze płyciny otrzymały nietypowy kształt przypominający dziurkę od klucza. Dodatkowo, u góry szczytu znalazła się jeszcze pojedyncza blenda, w którą wpisano trójlistną rozetkę, podobną do znajdujących się w skrajnych płycinach strefy pierwszej.

Rzut pionowy bocheńskiej fary był pierwotnie prawdopodobnie zbliżony do dzisiejszego - istniejące sklepienia zawieszone zostały zaraz pod koroną murów (il. 5) i nie zachowały się nad nimi żadne relikty pierwotnej artykulacji, także tam, gdzie należałoby się ich spodziewać, czyli na murze ponad arkadami międzynawowymi, ze względu na układ pseudobazylikowy sięgającym wyżej niż sklepienia naw bocznych (il. 6). W południowej ścianie prezbiterium prezbiterium, w pierwszym przęśle od zachodu, zachował 
8. Bochnia, kościót św.

Mikołaja, fasada, ubytki

w tynku w przyporze poprzecznej. Fot. Piotr Knapik

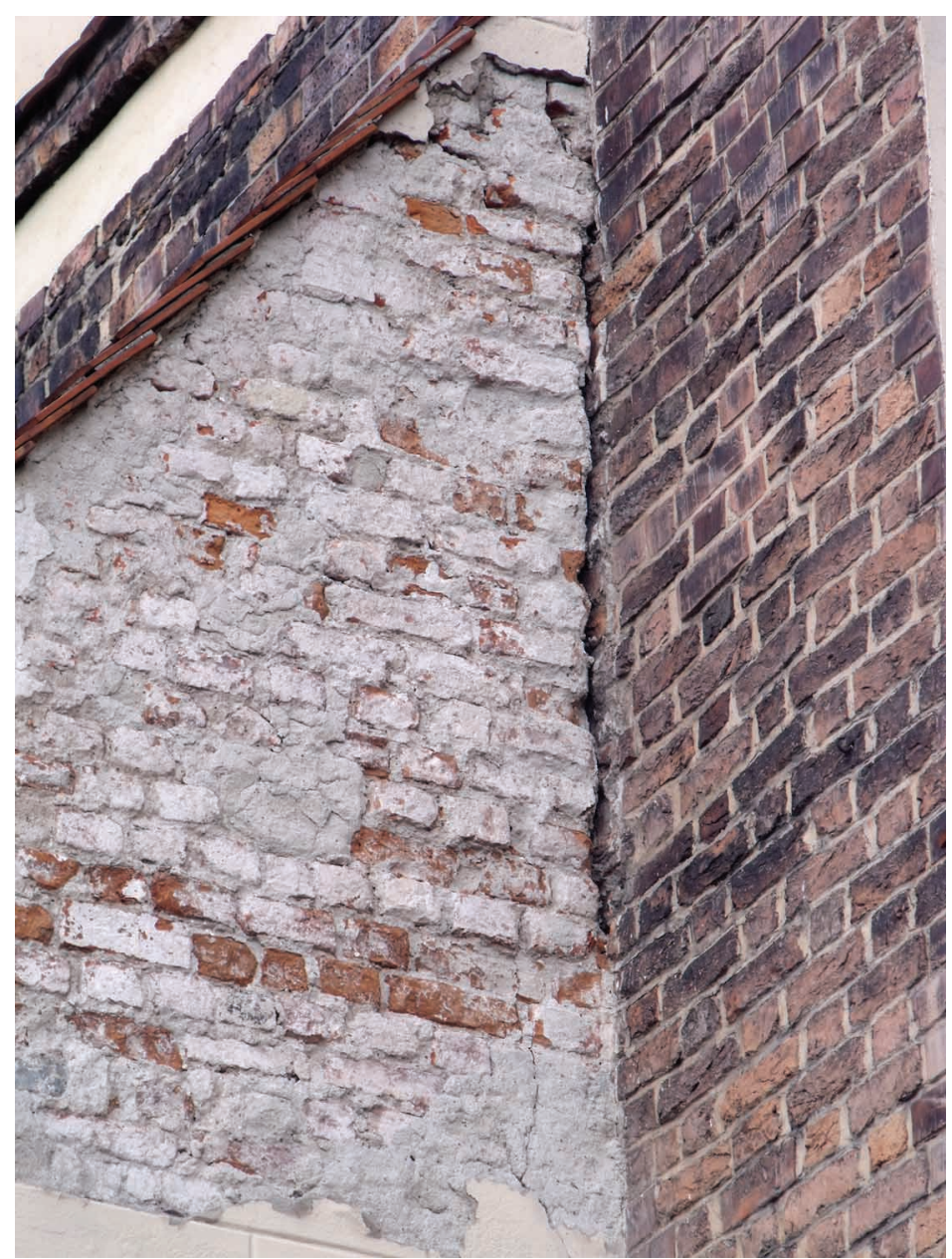

się natomiast relikt górnej części okna (il. 7). Pierwotnie zapewne wychodziło ono na zewnątrz, obecnie znajduje się pomiędzy chórem a kaplicą Mariacką. Ze względu na fakt, że wysokość tej kaplicy jest równa wysokości naw bocznych kościoła, a w konsekwencji jest ona niższa niż prezbiterium, także i wspomniane okno jest obecnie nieco niższe niż pierwotnie, a jego najwyższa część została zamurowana, czego efektem jest znajdujący się na strychu relikt. Spostrzeżenia te każą domniemywać, że pierwotne sklepienie chóru, a zapewne także i naw, znajdowało się na tej samej wysokości co obecnie lub ewentualnie nieznacznie wyżej. Nie można natomiast niczego pewnego stwierdzić o jego formie. Jednakże biorąc pod uwagę fakt, że zgodnie z średniowieczną praktyką budowlaną sklepienia powstały zapewne po wykonaniu więźby dachowej i szczytu, to (jeśli przyjać datowanie szczytu na przełom wieku XV i XVI lub 1. ćwierć XVI w.) można przypuszczać, że miały bogate układy kompozycyjne ${ }^{65}$.

Za jedyną zachowaną w pierwotnym kształcie część wnętrza trzeba uznać kaplicę św. Kingi. Nie ma żadnego powodu by wątpić w przekaz Demetrykiewicza ${ }^{66}$, potwierdzającego autentyczność przekrywających ją sklepień. Dowodzi tego również ich analiza: mają

\footnotetext{
${ }^{65} \mathrm{O}$ późnogotyckich sklepieniach w Polsce zob. Józef Tomasz FraziK, „Sklepienia żebrowe w Polsce XV wieku”, w: Sztuka i ideologia XV wieku. Materiały sympozjum Komitetu Nauk o Sztuce Polskiej Akademii Nauk, Warszawa, 14 grudnia 1976 r., red. Piotr SkuBIszewski (Warszawa: PWN, 1978), s. 521-566.

66 „Z protokołów posiedzeń Grona”, s. 366; według Teofila Wojciechowskiego stało się to w latach 1731-1773; zob. Wosciechowsкi, Kościelne dzieje Bochni w czasach staropolskich, s. 27.
} 


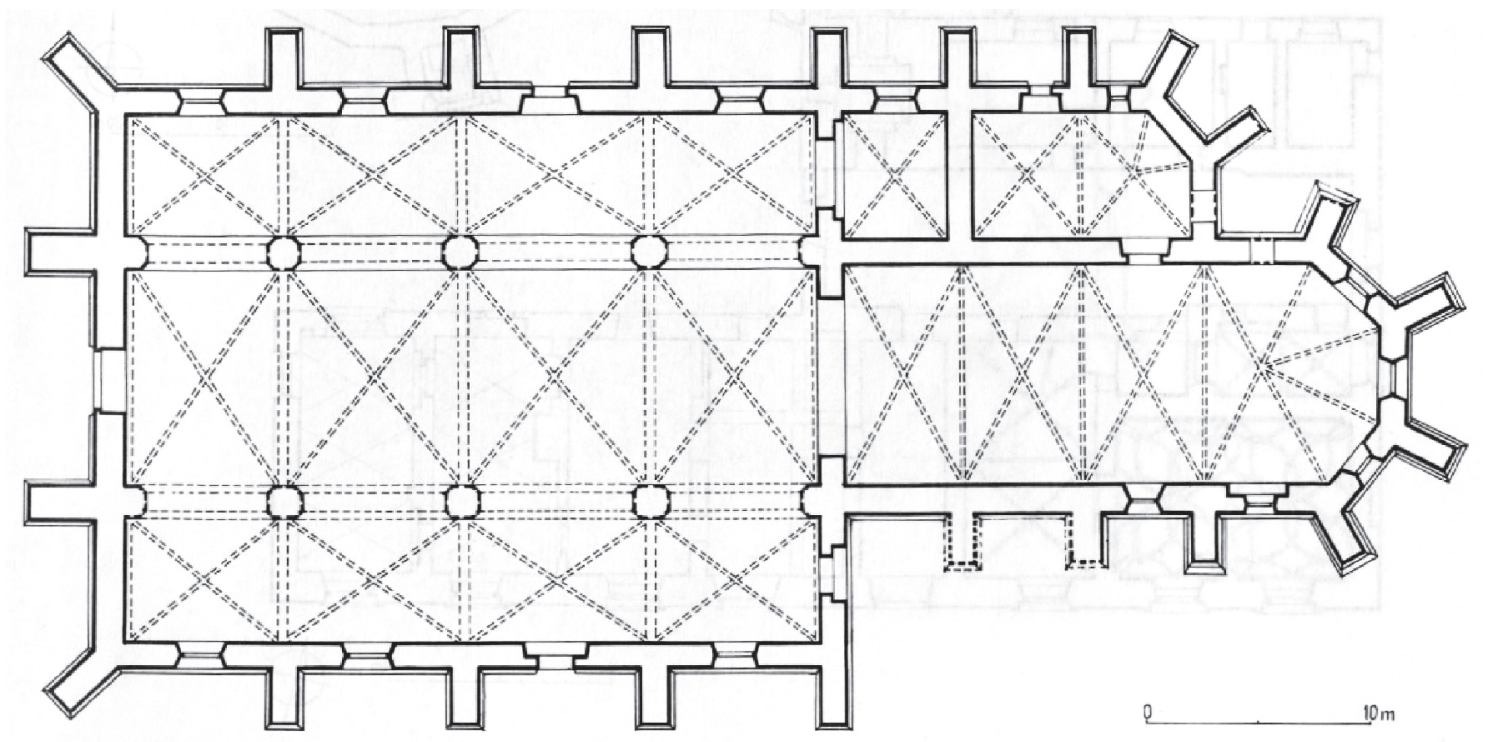

9. Bochnia, kościót św. Mikołaja, rzut. Wg Architektura gotycka w Polsce, t. 2, s. 353, il. 23

one wklęsłe profile typowe dla małopolskiej architektury końca XV i początku XVI w. ${ }^{67}$, a niedoskonałość ich wykonania i stan zachowania (widoczne rysy, nierówności itp.) także sugerują raczej średniowieczne niż XIX-wieczne pochodzenie.

Dość dużym zmianom poddana została w czasie neogotyckiej modernizacji fasada zachodnia. Analiza zdjęcia Demetrykiewicza (il. 2) pozwala stwierdzić, że pierwotnie szczyt nie miał sterczyn i był jedynie dwustrefowy. Potwierdza to także fakt, że cegły w trzeciej strefie i ponad nią są obecnie maszynowe, podczas gdy w dwóch pierwszych strefach w znacznej mierze zachował się materiał oryginalny. Stare cegły pozostały również we fryzie, który, choć na zdjęciu jest zatynkowany i niewidoczny, można na tej podstawie uznać za pierwotny. Wtórne są natomiast dwie prostopadłe do fasady przypory, które są bezuskokowe (odmiennie od pozostałych) i nieprzewiązane z jej murem (il. 8). Ponieważ występują już na planie z 1782 r., prawdopodobnie zostały dodane w czasie XVII-wiecznej odbudowy.

Plan bocheńskiej fary charakteryzuje się połączeniem czteroprzęsłowego, trójnawowego korpusu z wydłużonym prezbiterium (il. 9). Takie rozwiązanie chórów, choć wywodzi się z budownictwa mendykanckiego ${ }^{68}$, w wieku XIV stopniowo przyjęło się także w kościołach parafialnych. Jak trafnie zauważył Włodarek, analogie dla omawianego planu można znaleźć w architekturze czeskiej, m.in. w kościołach w Jindřichův Hradcu (ok. 1360-1370) czy św. Szczepana (2. połowa XIV w.) i św. Henryka w Pradze (2. połowa XIV lub początek XV w. $)^{69}$. Do spostrzeżeń badacza można jeszcze dodać także fary w Nymburku (1. połowa XIV w. ${ }^{70}$ ), Hradcu Králové (po 1339 - lata 90. w. XIV w. ${ }^{71}$ ),

\footnotetext{
${ }^{67}$ FrazIK, „Sklepienia żebrowe w Polsce XV wieku”, s. 523.

${ }^{68}$ Andrzej GrZYBKowski, „Zagadnienie długich chórów kościołów mendykanckich w Europie Środkowo-Wschodniej w XIII wieku", w: Franciszkanie w Polsce średniowiecznej, cz. 2-3: Franciszkanie na ziemiach polskich, red. Jerzy KŁoczowski (Kraków: Prowincjałat OO. Franciszkanów Konwentualnych Prowincji św. Antoniego i bł. Jakuba Strepy, 1989), s. 227-248; o architekturze zakonów mendykanckich zob. Wolfgang SchenKLuHn, Architektur der Bettelorden: Die Baukunst der Dominikaner und Franziskaner in Europa (Darmstadt: Wissenschaftliche Buchgesellschaft, 2000). ${ }^{69}$ WŁodAREK, „The Gothic Church of the Benedectines' Abbey at Tyniec”, s. 52.

${ }^{70}$ Dobroslav LoBro, Gotická architektura v Čechách a na Moravě (Praha: Umělecká beseda, 1948), s. 95, 139.

${ }^{71}$ Ibid., s. 146; Dalibor PRIX, „Związki śląsko-czeskie w architekturze średniowiecznej w okresie panowania Luksemburgów", w: Ślask. Perła w koronie czeskiej. Historia, kultura, sztuka, kat. wyst., Akademia Rycerska, Legnica, Valdštejská
} 


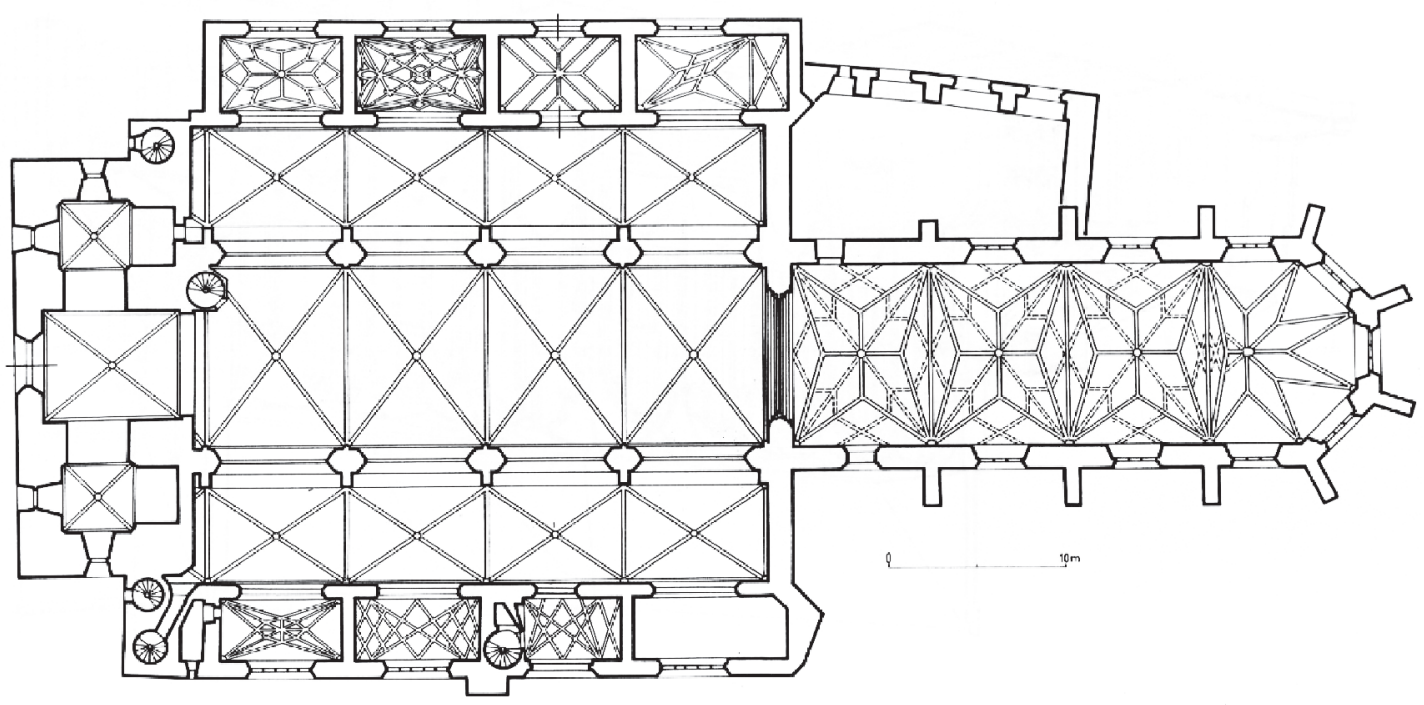

10. Kraków, kościót Mariacki, rzut. Wg Architektura gotycka w Polsce, t. 2, s. 434, il. 197

Mariacką w Kutnej Horze (3. ćwierć XIV w. ${ }^{72}$ ), Chrudimiu (3. ćwierć XIV w. - ok. 140073) i Vysokim Mýcie (3. ćwierć XIV w. - ok. 140074). Zestawienie długich chórów i krótkich korpusów cechuje także szereg budowli śląskich, takich jak kolegiata Św. Krzyża we Wrocławiu $\left(1288\right.$ - ok. $1380^{75}$ ) oraz fary w Grodkowie (4. ćwierć XIII w. ${ }^{76}$ ), Byczynie (ok. $1300^{77}$ ), Jaworze (ok. 1310 - pocz. w. XV w. ${ }^{78}$ ), Paczkowie (ok. 1350 - przed $1389^{79}$ ), Świerzawie (ok. 1370 - przed $1392^{80}$ ), Wołowie (4. ćwierć XIV w. - 1408 ${ }^{81}$ ), Jeleniej Górze (ok. 1380-1425 $5^{82}$ ), Głogówku (przełom XIV i XV w. ${ }^{83}$ ) i Ząbkowicach Śląskich (2. połowa $\mathrm{XIV}$-2. dekada XV w. ${ }^{84}$ ). Podobne plany w omawianym okresie zyskały popularność także w Małopolsce. Połączenie prostokątnego, najczęściej czteroprzęsłowego korpusu z wydłużonym prezbiterium pojawia się w grupie tzw. bazylik krakowskich, gdzie rozwiązanie to wykształciło się pod wpływem stołecznego kościoła dominikanów ${ }^{85}$, a następnie trafiło do

jízdárna, Praga, red. Mateusz Kapustka, Jan Klípa, Andrzej Kozię, Piotr Oszczanowski, Vít Vlnas (Praha: Národní Galerie; Legnica: Muzeum Miedzi, 2007), s. 154-155.

72 Ibid., s. 163.

${ }^{73}$ Dobroslav LíBAL, Gotická architektura v Čechách a na Moravě (Praha: Umělecká beseda, 1948), s. 145.

${ }^{74}$ Ibid., s. $145-146$.

${ }^{75}$ Jakub AdAMSKI, Gotycka architektura sakralna na Ślasku w latach 1200-1420. Główne kierunki rozwoju (Kraków: Towarzystwo Naukowe „Societas Vistulana”, 2017), s. 329-347, 411-431.

${ }^{76}$ Ibid., s. 188-195.

${ }^{77}$ Ibid., s. 202-211.

${ }^{78}$ Ibid., s. 388-391, 601-604.

${ }^{79}$ Ibid., s. $582-588$.

${ }^{80}$ Ibid., s. 597-601.

${ }^{81}$ Ibid., s. 595-597.

${ }^{82}$ Ibid., s. 550-559.

${ }^{83}$ Ibid., s. 579-582.

${ }^{84}$ Jakub ADAMSKI, „Gotycka fara św. Anny w Ząbkowicach, a tradycja i innowacja w architekturze sakralnej Śląska XIVXVI wieku”, w: Wokót dziejów miasta. 730 lat Ząbkowic Śląkich. Materiały z konferencji naukowej, red. Kamil PAwŁowski (Ząbkowice Śląskie: Biblioteka Publiczna Miasta i Gminy im. Księgi Henrykowskiej, 2017), s. 187.

${ }^{85}$ Tomasz WęCŁawowicz, Gotyckie bazyliki Krakowa: ,, czyli można konstrukcję kościołów krakowskich XIV wieku uważać za cechę specjalnq ostrołuku w Polsce?" (Kraków: Wydawnictwo Wawelskie, 1993), s. 23-25. 


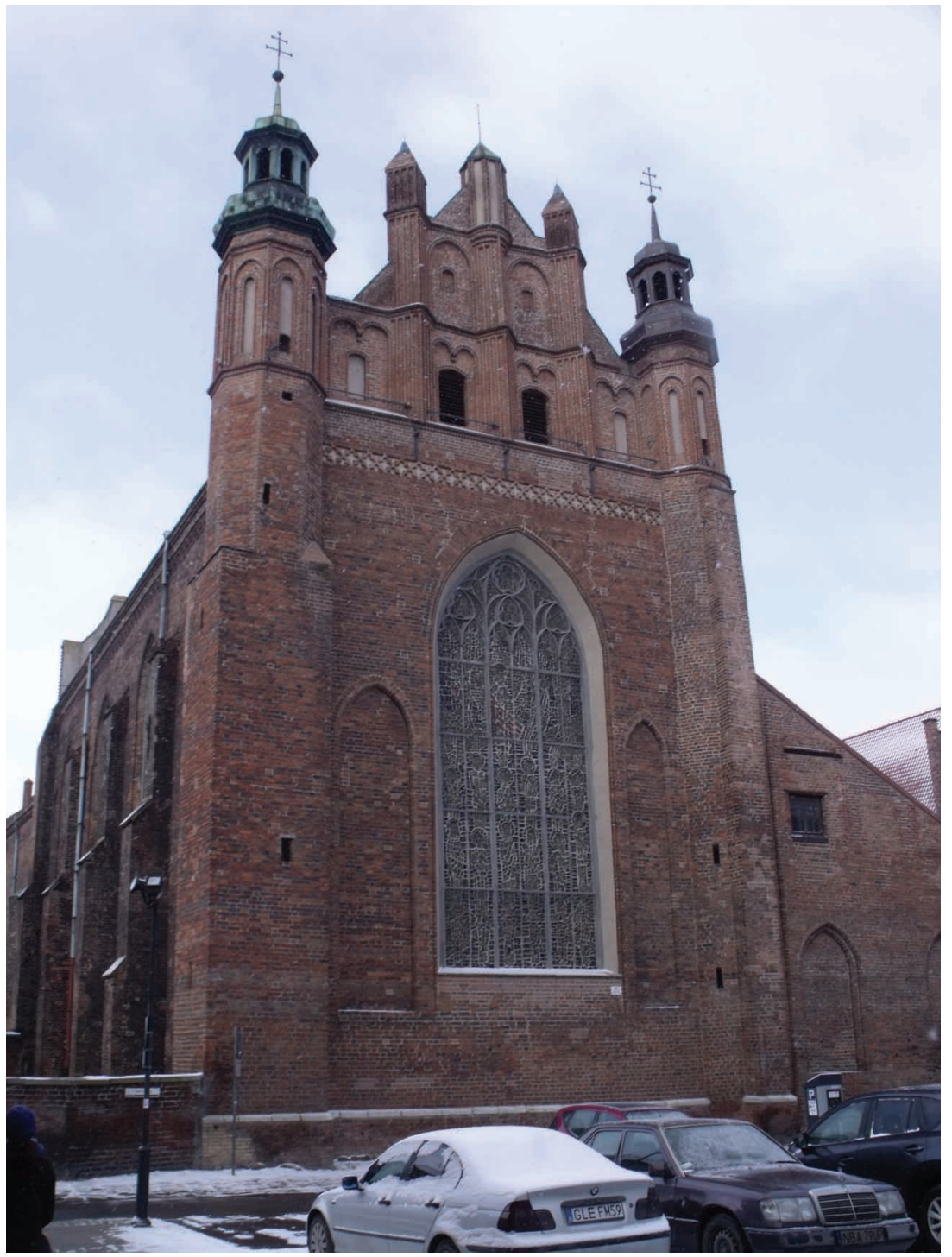

11. Gdańsk, kościół karmelitów (obecnie oblatów), szczyt wschodni.

Fot. Piotr Knapik

kościołów na prowincji, np. kolegiat w Sandomierzu (połowa XIV w. ${ }^{86}$ ) i Bodzentynie (ok. połowy $\mathrm{XV} \mathrm{w} \cdot{ }^{87}$ ). Planem takim cechuje się także omawiany przez Włodarka kościół benedyktynów w Tyńcu, który jednak, jak wykazał badacz, ma czeską genezę ${ }^{88}$. Małopolskie i Śląskie realizacje oddziałały także dalej na wschód, gdzie ich wypadkową stanowi katedra łacińska we Lwowie (lata 60. XIV - koniec XV w. ${ }^{89}$ ).

\footnotetext{
${ }^{86}$ Marek WALCZAK, „Z najnowszych odkryć gotyckiego malarstwa ściennego (prezbiterium katedry w Sandomierzu i kościół parafialny w Lubecku)", w: Imagines pictae. Studia nad malarstwem gotyckim w Polsce, red. Wojciech WALANus, Marek WalczaK (Kraków: Wydawnictwo Towarzystwo Naukowe „Societas Vistulana”, 2016) s. 187-198 (Studia z Historii Sztuki Średniowiecznej Instytutu Historii Sztuki Uniwersytetu Jagiellońskiego, 4).

${ }^{87}$ Odbudowa po pożarze w 1413 r. z fundacji Zbigniewa Oleśnickiego, który w 1440 r. przeniósł do niego zgromadzenie kanoników z Kielc; prace budowlane toczyły się jeszcze po roku 1454; zob. Marek WALCZAK, „Działalność fundacyjna biskupa krakowskiego, kardynała Zbigniewa Oleśnickiego”, Foliae Historiae Artium 28 (1992), s. 60.

${ }^{88}$ WŁodareK, „The Gothic Church of the Benedectines’ Abbey at Tyniec”, s. 52.

${ }^{89}$ Jakub ADAMSKI, „Gotycka architektura katedry łacińskiej we Lwowie - problem na nowo rozpatrzony”, w: Katedra, ratusz, dwór. Wielkie miasta a władza świecka i kościelna w kulturze średniowiecznej Europy, red. Jacek KowALSKI, Tomasz RATAJCZAK (Poznań: PTPN, 2014), s. 9-17.
} 


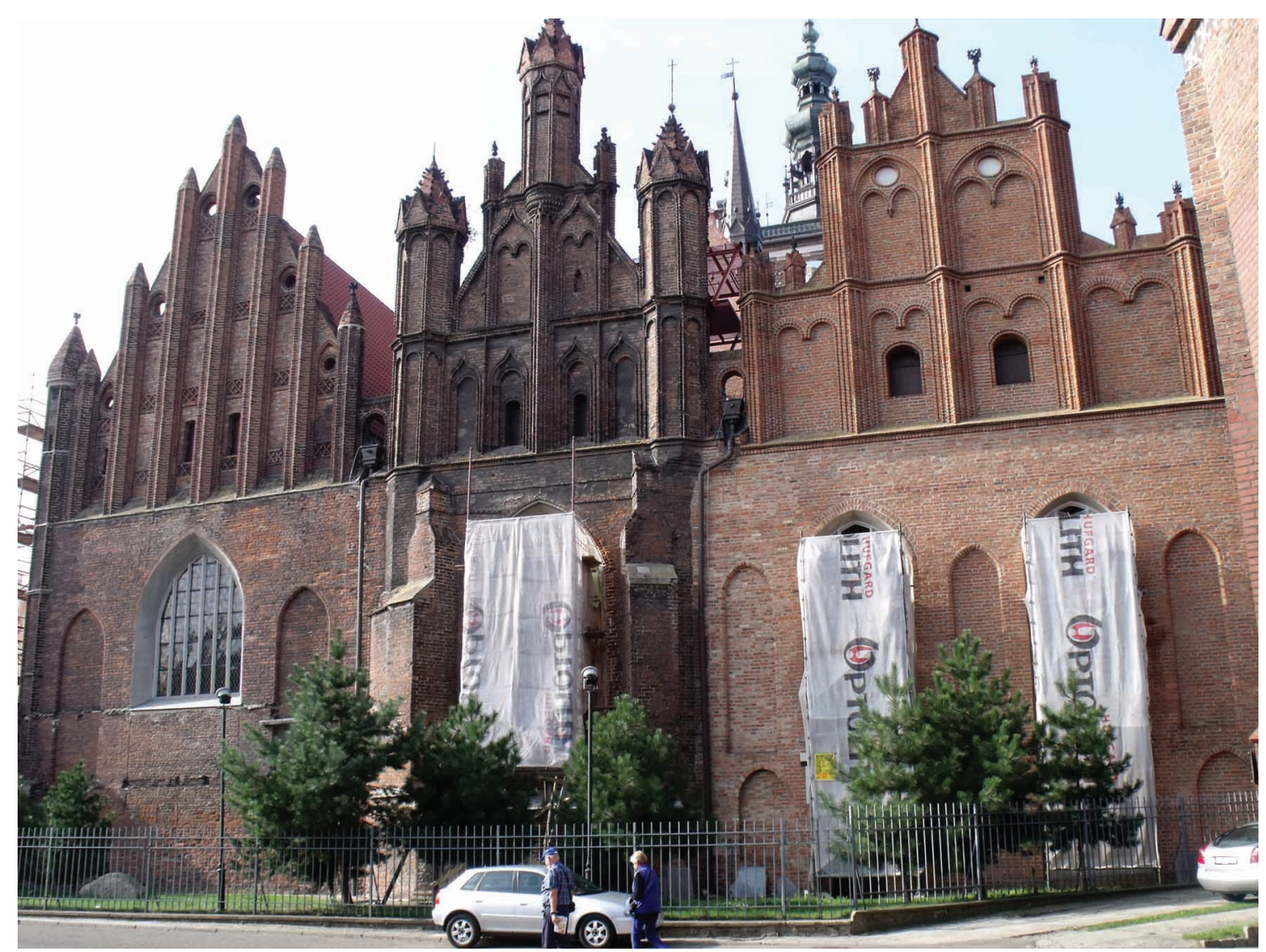

12. Gdańsk, kościót św. Katarzyny, widok od wschodu. Fot. Piotr Knapik

Szczególny wzór dla Bochni mógł stanowić zwłaszcza kościół Mariacki w Krakowie (prezbiterium przed $1360-1365^{90}$, korpus 1360/1365-1399 ${ }^{91}$ ). Rzuty poziome obu świątyń są niemal identyczne ${ }^{92}$ (il. 10), a jednocześnie trudno wyobrazić sobie lepszy model dla fary bogatego miasta górniczego niż nowa fara stolicy. Trzeba jednak podkreślić, że mogła być to co najwyżej ogólna inspiracja, a nie intencjonalne kopiowanie, tym bardziej że proporcje obu kościołów znacząco się od siebie różnią. Jak dowodzą liczne przytoczone wcześniej przykłady, omawiana budowla wpisuje się raczej w szeroki nurt rozwojowy środkowoeuropejskich kościołów parafialnych.

\footnotetext{
${ }^{90}$ Józef LepiarcZYK, „Fazy budowy kościoła Mariackiego w Krakowie (wiek XIII-XV)”, Rocznik Krakowski 34 (19571959), s. 195-207; Paul CrossLey, Gothic Architecture in the Reign of Kasimir the Great: Church Architecture in Lesser Poland 1320-1380 (Kraków: Ministerstwo Kultury i Sztuki, Zarząd Muzeów i Ochrony Zabytków, 1985), s. 399-400 (Biblioteka Wawelska, 7); WĘcŁawowicz, Gotyckie bazyliki Krakowa, s. 11-12.

${ }^{91}$ Paweł Pencakowski, „Kiedy powstał gotycki korpus bazylikowy kościoła Mariackiego w Krakowie i kto go budował?", w: Magistro et Amico amici discipulique. Lechowi Kalinowskiemu w osiemdziesięciolecie urodzin, red. Jerzy GADOMSKi et al. (Kraków: Wydawnictwo Uniwersytetu Jagiellońskiego, 2002), s. 245-255.

${ }^{92}$ Kaplice w kościele Mariackim są późniejsze i pochodzą dopiero z XV w.; zob: Marek WALCZAK, „Niekol'ko úvah o architektúre neskorogotických meštianskych kaplniek pri Mariánskom kostole v Krakove”, w: Pocta Václavovi Menclovi. Zbornik štúdii k otázkam interpretácie stredoeurópskeho umenia, red. Dana BoŘUTovÁ, Štefan ORIšKo (Bratislava: Katedra dejín výtvarnéhov umenia Filozofickej fakulty Univerzity Komenského, 2000), s. 193-208; Krzysztof CzYżEwSKI, Marek WALCZAK, „Late Gothic Architecture in the Region of Lesser Poland and its Central European Connections. Selected Issues", w: Die Länder der böhmischen Krone und ihre Nachbarn zur Zeit der Jagiellonenkönige (14711526): Kunst-Kultur - Geschichte, red. Evelin WeTter (Ostfildern: Jan Thorbecke, 2004), s. 326-330 (Studia Jagellonica Lipsiensia, 2).
} 
Szczyt bocheńskiej fary jest bardzo nietypowy na tle architektury gotyckiej Małopolski, która pod tym względem cechowała się dużym tradycjonalizmem ${ }^{93}$. Zazwyczaj powtarzano dwa typy, wypracowane jeszcze w wieku XIV - prosty, trójkątny oraz schodkowy ze sterczynami ${ }^{94}$. W obu tych odmianach w pole szczytu wpisane są przechodzące przez całą jego wysokość pionowe blendy, w drugiej z wersji często dodatkowo rozdzielone ustawionymi na kant lizenkami na osi sterczyn, które powyżej przechodzą w kamienny pinakiel ${ }^{95}$. W przeciwieństwie do nich szczyt bocheński jest wielostrefowy i podkreślono $\mathrm{w}$ nim raczej kierunki wertykalne niż horyzontalne (fryzy zamiast lizen), a same płyciny otrzymały kształt nietypowy dla Małopolski ${ }^{96}$. O ile dla niezwykłego, przypominającego dziurki od klucza wykroju blend w drugiej strefie ciężko jest znaleźć jakiekolwiek analogie, choć nieco zbliżone formy można znaleźć w maswerkach balustrady w sieni klasztoru augustianów w Krakowie z 4. ćwierci XIV w. ${ }^{97}$, a także w kwaterze z Naigrawaniem w poliptyku augustiańskim Mikołaja Haberschracka $\left(1468^{98}\right)$, to już zarówno łuki w ośli grzbiet, jak i zamknięcie za pomocą podwójnego łuku pełnego (aczkolwiek bez dodatkowego, trzeciego łuku powyżej) były popularnym rozwiązaniem w kościołach gdańskich końca wieku XV i początku XVI ${ }^{99}$. To drugie rozwiązanie pojawia się, być może jako wyraz tendencji romanizujących ${ }^{100}$, w elewacjach dworu bractwa św. Jerzego (1487-1494 ${ }^{101}$ ), a także w szczytach wschodnich kościołów franciszkanów (ukończony $1495^{102}$ ), karmelitów (obecnie oblatów, 1495-1496; il. 11 ${ }^{103}$ ) i św. Katarzyny (początek XVI w. ${ }^{104}$ ). Łuki w ośli grzbiet trafiają natomiast do Gdańska z Saksonii, najprawdopodobniej za pośrednictwem franciszkanów, którzy na przełomie XV i XVI w.

\footnotetext{
${ }^{93}$ WĘCLAWOwICZ, „Małopolska”, s. 80; Waldemar KomorowsKI, „Gotyk w architekturze Małopolski XVI wieku. Artykuł przeglądowy", w: Historyzm. Tradycjonalizm. Archaizacja. Studia z dziejów świadomości historycznej w średniowieczu i czasach nowożytnych, red. Marek WALCZAK (Kraków: Wydawnictwo Towarzystwo Naukowe „Societas Vistulana”, 2015), s. 198 (Studia z Historii Sztuki Średniowiecznej Instytutu Historii Sztuki Uniwersytetu Jagiellońskiego, 5).

${ }^{94}$ Zygmunt Świechowski, „Regiony w późnogotyckiej architekturze Polski”, w: Późny gotyk. Studia nad sztuka przełomu średniowiecza i czasów nowych. Materiały sesji Stowarzyszenia Historyków Sztuki, Wrocław 1962 (Warszawa: PWN, 1965), s. 128; WęCŁaWowicz, „Małopolska”, s. 79-80.

${ }^{95}$ Wyjątek stanowią wczesne przykłady w Olkuszu i Beszowej, gdzie znajdują się odpowiednio pomiędzy sterczynami i na ich krawędziach, a także w kościele dominikanów w Krakowie (szczyt zachodni), gdzie na sterczynach pojawiają się pinakle pomimo braku lizenek.

${ }^{96}$ Wyjątek stanowią szczyty librarii Collegium Maius i fary w Kraśniku, gdzie płyciny są również zamknięte łukiem w ośli grzbiet, jednak przy zupełnie innej kompozycji całości.

97 Tomasz WęcŁawowicz, Małgorzata Pietrzykówna, „Maswerki w kościołach Małopolski”, Rocznik Krakowski 55 (1989), s. 65-66.

${ }^{98}$ Muzeum Narodowe w Krakowie, nr inw. MNK I-603.

${ }^{99}$ Christofer Herrmann, Mittelalterliche Architektur im Preussenland. Untersuchungen zur Frage der Kunstlandschaft und-geographie (Petersberg: Michael Imhof, 2007), s. 171; ID., „Deutschordensland Preussen”, w: Mittelalterliche Architektur in Polen, red. Christofer Herrmann, Dethard von Winterfeld (Petersberg: Michael Imhof, 2015), t. 2, s. 1023 (Studien zur internationalen Architektur- und Kulturgeschichte, 56).

100 Tadeusz ChrZanowski, Marian Kornecki, „Pomorze Wschodnie”, w: Architektura gotycka w Polsce, t. 1, s. 108; na temat zjawiska odrodzenia romanizmu w Polsce zob. Zygmunt Świechowski, „Zagadnienie odrodzenia romanizmu w Polsce”, Biuletyn Historii Sztuki 22, nr 1 (1960), s. 339-350.

${ }^{101}$ Miłada Jędrysik, „Dwór bractwa św. Jerzego w Gdańsku”, Porta Aurea 1 (1992), s. 236.

102 Jakub SzCZEPAŃSKI, „Prezbiterium kościoła franciszkanów w Gdańsku i jego lektoria”, Kwartalnik Architektury i Urbanistyki 18, z. 2 (1993), s. 114.

${ }^{103}$ Hanna DomańskA, „Gdańsk. Kościół pw. proroków Eliasza i Elizeusza, karmelitów”, w: Architektura gotycka $w$ Polsce, t. 2, s. 80.

${ }^{104}$ Iwona STRZELECKA, Andrzej WŁodAREK, „Gdańsk. Kościół par. pw. św. Katarzyny”, w: Architektura gotycka w Polsce, t. 2 , s. 75 .
} 
wznosili w tym mieście swój kościół ${ }^{105}$. Ma on bardzo bogaty szczyt zachodni (ok. 1503$1514^{106}$ ), o konstrukcji opartej na filarach, pomiędzy którymi rozpięte są częściowo ażurowe wimpergi w ośli grzbiet. Podobne rozwiązanie znalazło się także w przylegającej do świątyni kaplicy św. Anny (ok. $1505^{107}$ ). Formy najbliższe bocheńskim wystapiły w szczycie wschodnim nad nawą główną kościoła św. Katarzyny (il. 12), również ukończonym na początku XVI w. ${ }^{108}$, gdzie pomiędzy dwoma bocznymi wieżyczkami i środkowym filarem umieszczono w dwóch strefach blendy zamknięte łukiem w ośli grzbiet, w które wpisane zostały kolejne, mniejsze blendy, w górnej strefie zamknięte podwójnym łukiem pełnym. Przykłady te mogłyby potwierdzać wysuwane przez większość badaczy przypuszczenia o wpływie ceglanego gotyku północnego na fasadę bocheńskiej fary, tym bardziej że późnogotycka architektura Gdańska wywarła znaczny wpływ na obszary sąsiednie (przede wszystkim Prusy, Litwę, Mazowsze i Wielkopolskę ${ }^{109}$ ), a wielu tamtejszych architektów było czynnych także w innych miastach ${ }^{110}$.

Istotną różnicą pomiędzy szczytami gdańskimi a rozwiązaniem zastosowanym w Bochni była jednak ich większa plastyczność, a także konsekwentne, silnie podkreślanie kierunków wertykalnych za pomocą wieżyczek, filarów i lizen, nie występujące w kościele będącym przedmiotem niniejszego opracowania. Wobec tego wydaje mi się zasadne wskazanie innego źródła inspiracji, jakim mogła być Saksonia. Późnogotyckie szczyty tego obszaru charakteryzowały się zupełnie inną kompozycją niż szczyty Brandenburgii, Pomorza czy Prus ${ }^{111}$. Podobnie jak w Bochni były one wielostrefowe, a poszczególne strefy często oddzielone były od siebie fryzami rombowymi, jak np. w Dünnebierhaus w Zwickau (ok. 1480112), Pohlhof w Altenburgu (ok. 1480 ${ }^{113}$ ), Thümerei (1484; il. $13^{114}$ ) i dawnym rektoracie przy Am Dom 2 (ok. $1484^{115}$ ) we Freibergu czy kościele franciszkanów w Kamenz na Łużycach (ok. 1500116). Blendy zazwyczaj zamknięte były łukami odcinkowymi - przykłady takiego rozwiązania znajdują się, poza wymienionymi już dziełami, na m.in. ratuszu w Miśni (ok. $1480^{117}$ ), kościele franciszkanów w tym

\footnotetext{
${ }^{105}$ Elżbieta PILECKA, ,Verbindungen zwischen der spätgotischen Architektur in Danzig und Mitteldeutschland”, w: Mittelalterliche Architektur und Bildende Kunst im Ostseeraum. Spezifik - Rezeption - Restaurierung, red. Artur BETHKE, Greifswald 1987, s. 47-48 (Wissenschaftliche Beiträge der Ernst-Moritz-Arndt-Universität Greifswald); GrzYBKowsKI, Gotycka architektura murowana w Polsce, s. 254-255.

${ }^{106}$ Marek Żydowicz, Andrzej WŁoDAREK, „Gdańsk. Kościół pw. Św. Trójcy, klasztor franciszkanów i kaplica pw. św. Anny", w: Architektura gotycka w Polsce, t. 2, s. 78-80.

${ }^{107}$ Ibid., s. $77-81$.

108 StrZelecka, WŁodareK, „Gdańsk. Kościół par. pw. św. Katarzyny”, s. 75.

109 PILECKA, „Verbindungen zwischen der spätgotischen Architektur in Danzig und Mitteldeutschland”, s. 48.

110 Np. Michael Enkinger, wznoszący kościoły św. Anny w Wilnie (1495-1501) i bernardynów w Warszawie (krużganki 1514, korpus od 1515); zob. Robert M. Kunkel, „Fundacje Aleksandra Jagiellończyka w Wilnie i Krakowie”, w: Sztuka około 1500. Materiaty Sesji Stowarzyszenia Historyków Sztuki, Gdańsk 1996 (Warszawa: ARX Regia Ośrodek Wydawniczy Zamku Królewskiego, Stowarzyszenie Historyków Sztuki, 1997), s. 132, 138-139.

${ }^{111}$ Późnogotyckie szczyty w Saksonii doczekały się swojej monografii, w której zagadnienie to jest szeroko omówione i podparte sporą ilością materiału porównawczego (z którego w niniejszym artykule, ze względu na ograniczone miejsce, prezentuję tylko pewien wybór). Zob. Matthias Donath, Spätgotische Giebel in Sachsen (Beucha: Sax-Verlag, 2001).

112 Ibid., s. 26, 38, 78, 133-134.

${ }^{113}$ Ibid., s. 26, 38, 77, 112-113.

${ }^{114}$ Ibid., s. 27-28, 38, 70, 115.

115 Ibid., s. 28, 38, 115.

116 Ibid., s. 34, 68, 119 .

${ }^{117}$ Ibid., s. 38, 74, 122-123.
} 


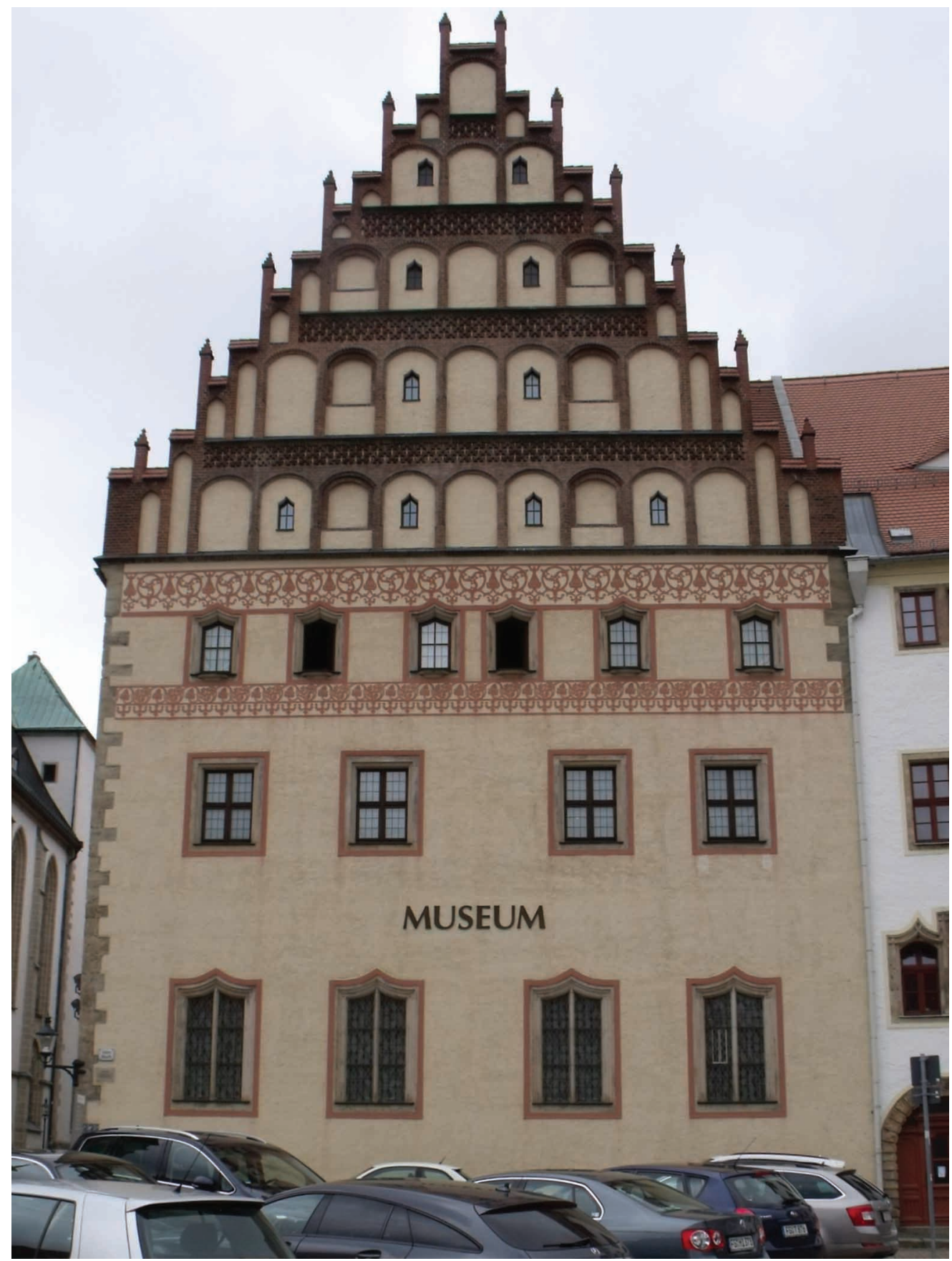

13. Freiberg, Thümerei. Fot. Piotr Knapik

samym mieście (ok. $1500^{118}$ ) czy farze w Kamenz (szczyt wschodni, koniec XV w. ${ }^{119}$ ). Zdarzało się jednak także stosowanie podwójnego łuku pełnego, np. w farach w Hoyerswerdzie (ok. $1500^{120}$ ) czy w Kamenz (szczyt zachodni, koniec XV w.; il. 14 ${ }^{121}$ ), a także w ośli grzbiet, np. w zamku biskupim w Wurzen (1491-1497 ${ }^{122}$ ) czy kościele Mariackim

\footnotetext{
${ }^{118}$ Ibid., s. 33, 68, 122.

${ }^{119}$ Ibid., s. 34, 68, 119.

${ }^{120}$ Ibid., s. 33, 68, 119.

${ }^{121}$ Ibid., s. 34, 68, 119.

${ }^{122}$ Ibid., s. 33, 72, 131.
} 


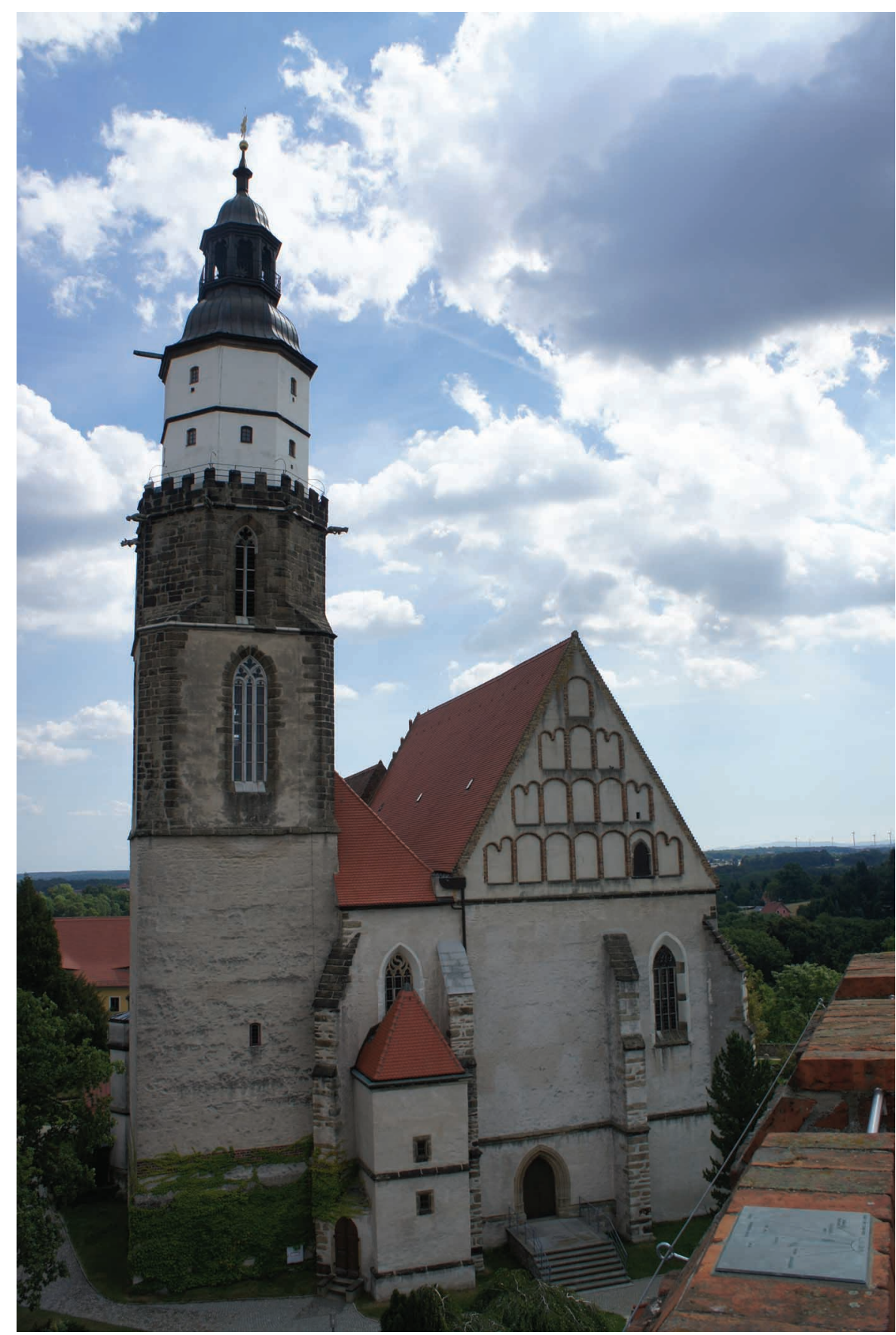

14. Kamenz, kościół Mariacki, widok od zachodu. Fot. Paulis, https:// de.wikipedia.org/wiki/Datei:Johanniskirche_Hoyerswerda.jpg

w Rötha (1510-1520123). Szczególnie podobny do bocheńskiej budowli jest zwłaszcza pseudobazylikowy kościół augustianów w Żaganiu (ok. 1515-1520; il. 15 ${ }^{124}$ ). Jego fasada i szczyt zdradzają ewidentny wpływ środowiska saskiego, wbrew sugestiom zarówno Hansa Tintelnota ${ }^{125}$, który widział w tym typowo śląskie motywy, jak i Mariana

\footnotetext{
${ }^{123}$ Ibid., s. 48, 68, 127.

${ }^{124}$ Marian KuTZNER, Studium historyczno-urbanistyczne zespołu poklasztornego w Żaganiu, Wrocław 1960, s. 48 (maszynopis w Narodowym Instytucie Dziedzictwa we Wrocławiu).

${ }^{125}$ Hans Tintelnot, Die mittelalterliche Baukunst Schlesiens (Kitzingen: Holzner-Verlag, 1951), s. 210.
} 


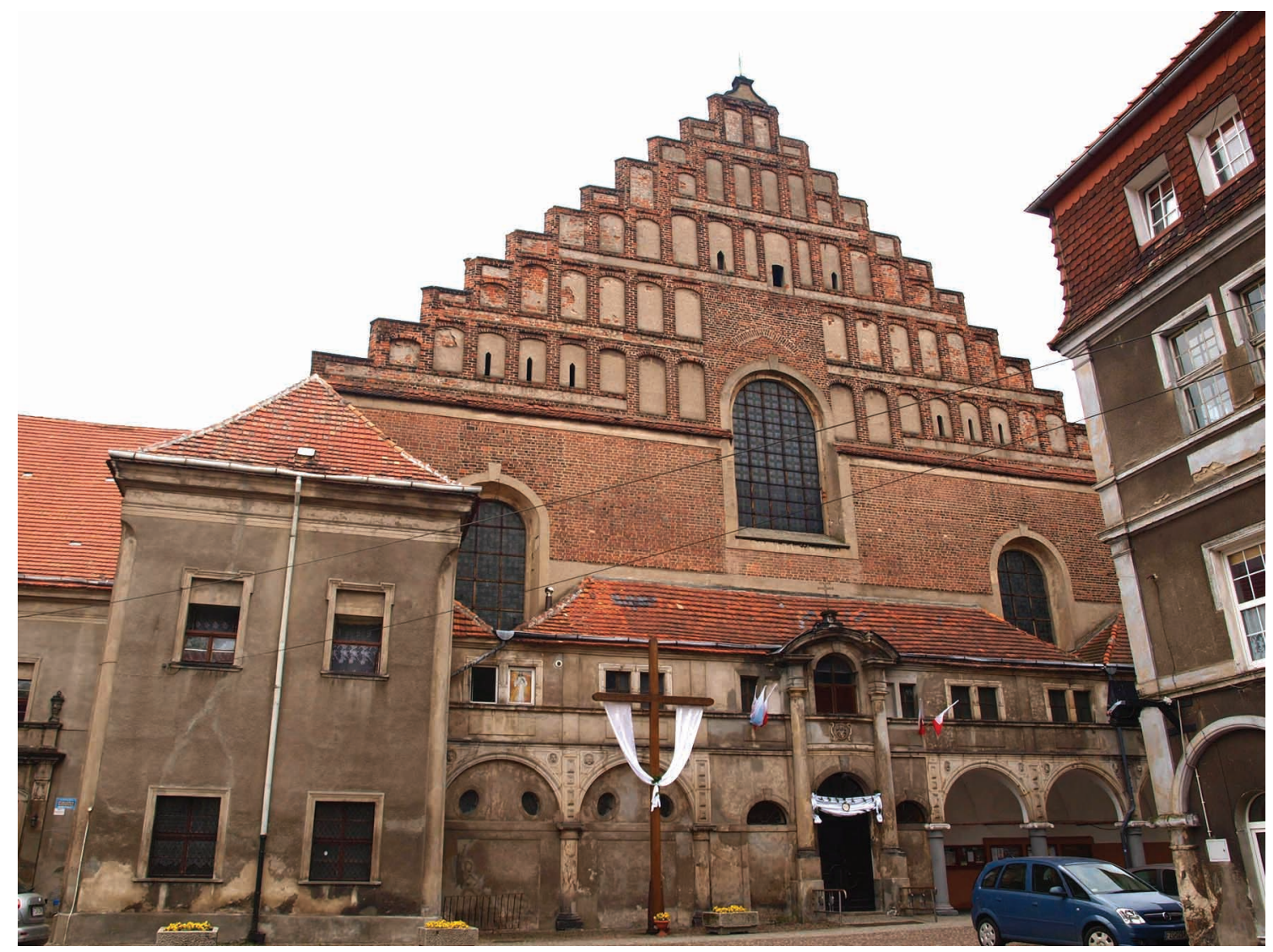

15. Żagań, kościól augustianów, fasada zachodnia.

Fot. Gabriela Citko

Kutznera $^{126}$, dostrzegającego oddziaływania brandenbursko-marchijskie. Ponadto w pole szczytu została tam nietypowo włączona część okna nawy głównej. Kompozycja ta bardzo przypomina fasadę w Bochni, być może jednak podobieństwo to wynika nie tyle $\mathrm{z}$ bezpośredniej inspiracji, ile po prostu z rozwiązania podobnego problemu architektonicznego, którym w obu przypadkach były pseudobazyliki o dość przysadzistych proporcjach. Sama hipoteza o wpływach saskich, ewentualnie zapośredniczonych przez Śląsk, jest jednak prawdopodobna, znane są bowiem oddziaływania tego obszaru na małopolską architekturę przełomu XV i XVI w. Dowodem na to jest przede wszystkim gmach Collegium Maius Uniwersytetu Jagiellońskiego z wywodzącymi się z Miśni sklepieniami kryształowymi (po 1493 ${ }^{127}$ ) i oknami o łukach kotarowych. Te pierwsze pojawiły się ponadto w tym czasie także w kaplicy przy południowej wieży kościoła św. Małgorzaty w Nowym Sączu ${ }^{128}$.

Trzeba jednak podkreślić, że wielostrefowe szczyty o dość horyzontalnej i linearnej kompozycji, przy jednoczesnym zastosowaniu łuków w ośli grzbiet, pojawiły się także w farze (obecnie katedrze) w Bydgoszczy (ok. 1500, wzniesiony najprawdopodobniej

\footnotetext{
${ }^{126}$ KuTzNeR, Studium historyczno-urbanistyczne zespolu poklasztornego w Żaganiu, s. 47-49.

${ }^{127}$ Karol EsTREICHER, „Collegium Maius. Dzieje gmachu”, Zeszyty Naukowe Uniwersytetu Jagiellońskiego CLXX. Prace z Historii Sztuki, z. 6 (1968), s. 85-86; Maria BRYKowsKA, „Sklepienia kryształowe: niektóre problemy”, w: Późny gotyk, s. 255; Milada i Oldřich Radovi, Kniha o sklipkových klenbách (Praha: Jalna, 1998), s. 90, 305; Bogusław KrasnowoLSKI, „Krakowskie warsztaty budowlane i kamieniarskie na przełomie średniowiecza i nowożytności”, Rocznik Krakowski 72 (2006), s. 93-94.

${ }^{128}$ RADOvi, Kniha o sklipkových klenbách, s. 314.
} 


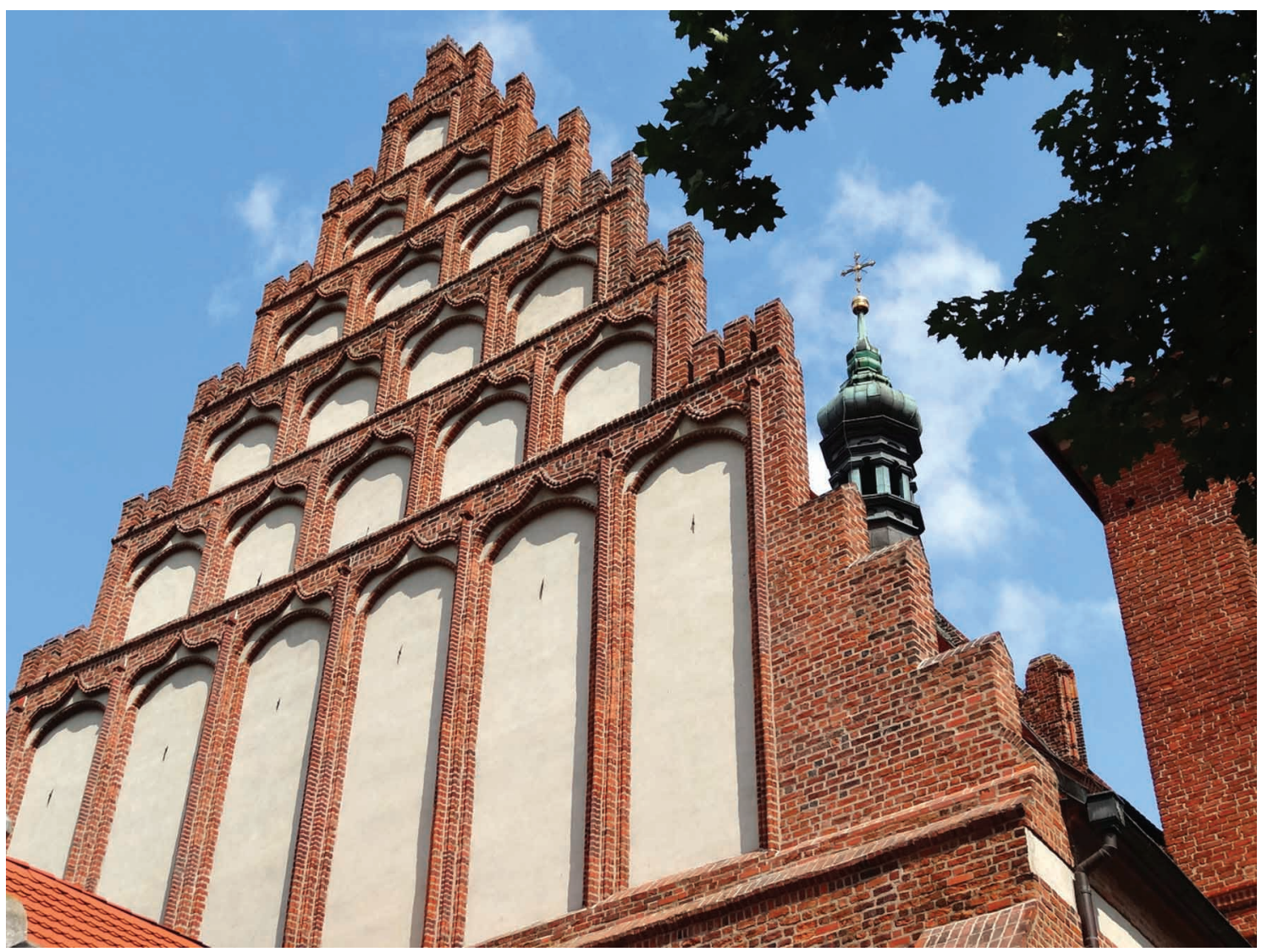

16. Bydgoszcz, fara (obecnie katedra), szczyt zachodni. Fot. Pit1233, https://pl.wikipedia.org/ wiki/Plik:Bdg_Katedra_15_07-2013.jpg

przez gdańskiego architekta; il. $\left.16^{129}\right)$, a także w powstałych pod jej wpływem rozwiązaniach w Wielkopolsce, m.in. w psałterii w Poznaniu (ok. 1512 ${ }^{130}$ ) czy kościołach w Kole (kaplica NMP, $1522^{131}$ ) i Gostyniu (kruchta, $1523^{132}$ ). Szczyty te tworzą jednak dość jednolitą grupę, o niewystępujących w Bochni elementach: wszystkie są schodkowe, mają sterczyny grupowane w charakterystyczny sposób po dwie lub trzy obok siebie i wymijające się osie blend w każdym z poziomów, dlatego też nie wydaje mi się, by mogły stanowić wzór dla omawianej tu budowli.

Ostatni, najtrudniejszy problem badawczy stanowi ustalenie chronologii budowy bocheńskiej fary, czego nie można przeprowadzić na podstawie źródeł pisanych. Utrudnione jest także datowanie w oparciu o analizę substancji architektonicznej ze względu na znaczne przelicowanie powierzchni ścian zewnętrznych. Wobec braku wyczerpujących badań architektonicznych i archeologicznych, na obecnym etapie może to zostać określone jedynie hipotetycznie, przede wszystkim w oparciu o analizę stylową.

Największe rozbieżności wśród badaczy budziły początki budowy kościoła i ich określenie faktycznie wydaje się najbardziej problematyczne. Zaproponowane przez Beiersdorfa

\footnotetext{
${ }^{129}$ Jacek KowaLSKI, „Pomiędzy Pomorzem, a Wielkopolską - gotycka architektura bydgoskiej katedry”, w: Kościót katedralny w Bydgoszczy, red. Aleksander JanKowski, Dariusz KARCZEwsKi (Bydgoszcz: Wydawnictwo Uniwersytetu Kazimierza Wielkiego, 2018), s. 30.

${ }^{130}$ ŚwIECHOWSKI, „Regiony w późnogotyckiej architekturze Polski”, s. 130.

${ }^{131}$ Ibid.

${ }^{132}$ Ibid.
} 
i Krasnowolskiego ${ }^{133}$ powiązanie świątyni ze staraniami Kazimierza Wielkiego o uzyskanie odpustów wydaje się kontrowersyjne. Odpusty były typową średniowieczną praktyką dewocyjną, która niekoniecznie musiała być powiązana ze zbieraniem środków na budowę nowego kościoła, tym bardziej że w treści królewskiej prośby mowa jest o udzieleniu odpustu wiernym, którzy jedynie odwiedzą świątynię, a nie wesprą jej budowę. W związku z tym należy zdecydowanie stwierdzić, że nie dysponujemy żadnymi pewnymi przesłankami pozwalającymi datować początek prac na wiek XIV.

Zgodnie ze średniowieczną praktyką budowlaną należy przyjąć, że prace posuwały się od części wschodniej na zachód, a zatem zaczęły się od prezbiterium. Określenie czasu ante quem końca jego budowy jest możliwe dzięki analizie malowidła przedstawiającego Rozesłanie Apostołów, znajdującego się w kaplicy św. Kingi na ścianie oddzielającej ją od chóru (il. 4). Porównanie jego dzisiejszego stanu ze zdjęciem z 1983 r. $^{134}$ dowodzi jednak, że zostało ono bardzo mocno uzupełnione, wobec czego wszelkie propozycje datowania muszą być traktowane bardzo ostrożnie. Najczęściej wskazywany koniec XV lub XVI w. ${ }^{135}$ to stanowczo zbyt późno w świetle zachowanych z tego okresu zabytków malarstwa ściennego i tablicowego w Małopolsce. Alternatywne datowanie na lata 70. XIV w., zasugerowane przez Korneckiego i Małkiewiczównę, którzy dopatrzyli się podobieństw do malarstwa czeskiego z kręgu mistrza Teodoryka ${ }^{136}$, wydaje się być z kolei zbyt wczesne. Przedstawienia Rozesłania Apostołów stają się w Małopolsce szczególnie popularne dopiero po 1410 r. jako nawiązania do bitwy pod Grunwaldem, która odbyła się właśnie w święto upamiętniające owo ewangeliczne wydarzenie ${ }^{137}$. W związku z tym także i datę zakończenia prac przy chórze można ustalić przed 2. ćwiercią XV w., przy czym nie można wykluczyć, że malowidło powstało po dłuższym czasie od wybudowaniu muru, na którym się znajduje.

Biorąc pod uwagę, że mało prawdopodobne jest, aby prace przy prezbiterium ciągnęły się aż od czasów Kazimierza Wielkiego, a także uwzględniając fakt, że bocheńska fara jest zapewne wtórna wobec krakowskiej, początek budowy chóru można ostrożnie wiązać z przekazem pochodzącym z 1405 r. Datowanie to jest jednak bardzo ogólne wobec niemożliwości dokładnego określenia czasu powstania malowidła i jego opóźnienia w stosunku do samych murów.

W następnej fazie wzniesiony został zapewne korpus kościoła. Trudno stwierdzić, do jakiego stopnia zniszczył farę pożar miasta z 1447 r., jednak odbudowa musiała postępować relatywnie szybko, skoro Długosz w Liber beneficiorum wymienił już kilka ołtarzy znajdujących się w świątyni ${ }^{138}$. Dużo bardziej destrukcyjny mógł być pożar z ok. 1485 r., w wyniku którego zapewne zawaliły się pierwotne sklepienia, a także zaszła konieczność wymiany więźby dachowej. Świadczy o tym szczyt w fasadzie zachodniej, który na podstawie jego formy można zadatować na przełom wieku XV i XVI lub 1. ćwierć XVI w.

\footnotetext{
${ }^{133}$ BeIersdorf, Krasnowolski, Bochnia: studium historyczno-urbanistyczne, t. 2, s. 16.

${ }^{134}$ Wóstowicz, Kościót parafialny w Bochni, s. 102.

${ }^{135}$ Hanna PIEŃKOwSKA, ,Znaczenie naukowe odkryć malowideł ściennych w Małopolsce południowej”, Ochrona Zabytków 30, nr 1-2 (1977), s. 7; KoRNECKI, „Dzieje sztuki regionu bocheńskiego”, s. 206; WóJTowicz, Kościół parafialny w Bochni, s. 103; WyCZESANY, Wystrój artystyczny kościoła św. Mikołaja w Bochni, s. 45; Flasza, Bochnia-przewodnik po mieście, s. 95-96.

${ }^{136}$ Marian Kornecki, Helena MaŁkiewiczówna, „Małopolska”, w: Gotyckie malarstwo ścienne w Polsce, red. Jerzy DomosŁawski et al. (Poznań: Wydawnictwo Naukowe Uniwersytetu im. Adama Mickiewicza, 1984), s. 44-45

${ }^{137}$ Marek WALCZAK, „Bitwa grunwaldzka a sztuka od wieku XV do końca XVIII”, w: Na znak świetnego zwycięstwa, t. 1: Studia, red. Dariusz NowACKI (Kraków: Zamek Królewski na Wawelu, 2010), s. 272-278.

${ }^{138}$ Deugosz, Liber beneficiorum dioecesis cracoviensis, s. 126.
} 
Z tego czasu (ok. 1520) pochodzi także zachowany fragment szczytu w położonym niedaleko Bochni Starym Wiśniczu, który ma analogiczny fryz rombowy ${ }^{139}$. Być może wtedy także przekryto kaplicę św. Kingi, jednak wklęsłe profile żeber pozwalają tylko na bardzo szerokie datowanie (ok. 1500), zatem sklepienie to mogło powstać jeszcze przed pożarem z ok. 1485 r. i przetrwać go nienaruszone.

Podsumowując powyższe rozważania, należy podkreślić, że nawet pomimo silnych przekształceń kościół św. Mikołaja w Bochni jest jednym z najlepiej zachowanych XVwiecznych kościołów tej wielkości w Małopolsce ${ }^{140}$. Jest on przy tym największą farą wzniesioną w tym czasie w regionie. Jednocześnie należy dokonać rewizji dotychczasowych negatywnych ocen szczytu w fasadzie. Jego forma, choć nie pociagnęła za sobą żadnych kontynuacji i pozostała odosobniona, jest pomimo niedoskonałości warsztatowych dowodem otwartości małopolskiego środowiska architektonicznego u schyłku gotyku na nowatorskie wpływy obcych środowisk, które docierały nie tylko do stołecznego Krakowa, ale i do miejscowości na prowincji.

$\mathrm{Na}$ koniec trzeba jeszcze wspomnieć o nietypowym, niespotykanym w innych kościołach małopolskich podziale murów na dolną strefę z kamienia i górną ceglaną. Zazwyczaj ściany wykonywano w całości z jednego tworzywa, wyjątek mógł stanowić jedynie sam cokół. Zróżnicowanie materiałów, jeśli już się pojawiało, najczęściej było efektem wykonywania prac w różnych fazach lub rozbudowywania starszych świątyń w późniejszych okresach $^{141}$. Wobec braku źródeł pisanych, przy jednocześnie dużym stopniu przelicowania murów, brakuje jednak podstaw, by twierdzić, że było tak i w Bochni. Konsekwentny podział zewnętrznej powierzchni ścian na dwie strefy wykonane z dwóch różnych materiałów, zarówno w prezbiterium, jak i w korpusie nawowym, wydaje się być raczej świadomym zabiegiem artystycznym, jednak bez dokładniejszych badań architektonicznych niemożliwe jest stwierdzenie tego z całą pewnością.

\footnotetext{
${ }^{139}$ KoRnECKI, „Dzieje sztuki regionu bocheńskiego”, s. 210.

${ }^{140} \mathrm{~W}$ znacznie większym stopniu przekształcone zostały kościoły benedyktynów w Tyńcu, paulinów w Częstochowie czy karmelitów na Piasku w Krakowie, a także fary w Proszowicach oraz w Oświęcimiu i Zatorze (dwie ostatnie zresztą w momencie powstania pozostające jeszcze poza granicami Korony Królestwa Polskiego).

${ }^{141}$ Por. np. wieża Srebrnych Dzwonów w katedrze wawelskiej czy kościół Św. Krzyża w Krakowie.
} 


\section{Architecture of the Gothic Parish Church in Bochnia}

The Bochnia Parish Church is a two-aisled four-bayed building of a pseudo-basilica type with a long fourbay triangularly closed chancel, the latter with two adjacent chapels on the extension of the aisles (one Gothic and the other from the $18^{\text {th }}$ century). Except for the first, the interiors of the discussed structure have not been preserved in their genuine form. The Church's architecture has not as yet been of much interest to researchers: generally, only dating has been provided and inspiration from the brick Gothic of the North suggested.

However, the analysis of an archival photo by Włodzimierz Demetrykiewicz allows to attempt a reconstruction of the Church's genuine appearance, from before the Gothic Revival remodelling conducted in 1901-06 after the design of Jan Sas Zubrzycki. On the occasion, the gable composition was altered by adding pinnacles and the third highest row of blind recesses; furthermore, a substantial part of the walls were refaced. Additionally, secondary are also two perpendicular buttresses in the western façade (they are not connected with its wall; furthermore, they are not offset, thus differing from the remaining buttresses) which were most likely created in the $17^{\text {th }}$ century. What may have resembled the today's shape was the Church's genuine vertical projection; this testified to by the fact that the existing vaults were suspended just below the wall crowns, and no relics of the original articulation have been preserved above them; what has been preserved instead is the relic of the window in the southern chancel wall in the first bay from the west. Originally, it looked out on the outside, whereas currently it is placed between the choir and the $18^{\text {th }}$-century Marian Chapel equalling the aisles in height.

The horizontal projection of the Bochnia Church shows a number of affiliations both with the architecture of Lesser Poland (particularly with the group of so-called Cracow basilicas headed by St Mary's Church in Cracow) and in Central Europe (a similar plan can be found in a substantial number of parish churches in Bohemia and Silesia). Moreover, the western gable is characteristic: it has its counterparts in some structures in Gdansk, but first and foremost in Saxony.

The current shape of the discussed building was most likely created in several stages: the oldest part is the chancel from ca the first quarter of the $15^{\text {th }}$ century, while the newest is the western gable created already at the turn of the $16^{\text {th }}$ century or in the first quarter of the latter. Regrettably, it is impossible to identify the exact chronology due to the insufficient number of written sources or the lack of exhaustive architectural and archaeological researches. 


\section{Bibliografia:}

Adamski, Jakub. "Gotycka architektura katedry łacińskiej we Lwowie - problem na nowo rozpatrzony." W Katedra, ratusz, dwór: Wielkie miasta a władza świecka i kościelna w kulturze średniowiecznej Europy, redakcja Jacek Kowalski, Tomasz Ratajczak, 9-31. Poznań: PTPN, 2014.

Adamski, Jakub. Gotycka architektura sakralna na Ślasku w latach 1200-1420: Główne kierunki rozwoju. Kraków: Towarzystwo Naukowe Societas Vistulana, 2017.

Adamski, Jakub. "Gotycka fara św. Anny w Ząbkowicach a tradycja i innowacja w architekturze sakralnej Śląska XIV-XVI wieku.” W Wokót dziejów miasta. 730 lat Ząbkowic Ślaskich: Materiały z konferencji naukowej, redakcja Kamil Pawłowski, 183-200. Ząbkowice Śląskie: Biblioteka Publiczna Miasta i Gminy im. Księgi Henrykowskiej, 2017.

Chrzanowski, Tadeusz, i Marian Kornecki. "Pomorze Wschodnie." W Architektura gotycka w Polsce, redakcja Teresa Mroczko, Marian Arszyński, t. 1, 93-109. Warszawa: Instytut Sztuki PAN, 1995.

Chrzanowski, Tadeusz, i Marian Kornecki. Sztuka Ziemi Krakowskiej. Kraków: Wydawnictwo Literackie, 1982.

Crossley, Paul. Gothic Architecture in the Reign of Kasimir the Great: Church Architecture in Lesser Poland 1320-1380. Kraków: Ministerstwo Kultury i Sztuki, Zarząd Muzeów i Ochrony Zabytków, 1985.

Czyżewski, Krzysztof, i Marek Walczak. "Late Gothic Architecture in the Region of Lesser Poland and its Central European Connections. Selected Issues." W Die Länder der böhmischen Krone und ihre Nachbarn zur Zeit der Jagiellonenkönige (1471-1526): Kunst - Kultur - Geschichte, redakcja Evelin Wetter, 326-330. Ostfildern: Jan Thorbecke, 2004.

Donath, Matthias. Spätgotische Giebel in Sachsen. Beucha: Sax-Verlag, 2001.

Flasza, Jan. Bazylika św. Mikołaja w Bochni. Bochnia: Parafia pw. św. Mikołaja; Tarnów: Wydawnictwo "S-Can", 2009.

Flasza, Jan. Bochnia - przewodnik po mieście. Bochnia: Urząd Miejski, 2015.

Flasza, Jan. "Dawne plany i widoki." W Atlas historyczny miast polskich, redakcja Roman Czaja, t. 5: Małopolska, redakcja Zdzisław Noga, z. 4: Bochnia, redakcja Zdzisław Noga, 13-14. Toruń: Wydawnictwo Naukowe Uniwersytetu Mikołaja Kopernika; Kraków: Uniwersytet Pedagogiczny, 2016.

Flasza, Jan. “Jak pokazać dzieje Bochni w obrazach.” Kronika Bocheńska 22, nr 3 (2014): 28-33.

Flasza, Jan. "Święta Kinga i Bochnia.” Tarnowskie Studia Teologiczne 18 (1999): 197-220.

Frazik, Józef Tomasz. "Sklepienia żebrowe w Polsce XV wieku.” W Sztuka i ideologia XV wieku: Materiały sympozjum Komitetu Nauk o Sztuce Polskiej Akademii Nauk, Warszawa, 1-4 grudnia 1976 r., redakcja Piotr Skubiszewski, 521-566. Warszawa: PWN, 1978.

Grzybkowski, Andrzej. Gotycka architektura murowana w Polsce. Warszawa: Wydawnictwo Uniwersytetu Warszawskiego, 2014. 
Grzybkowski, Andrzej. “Zagadnienie długich chórów kościołów mendykanckich w Europie Środkowo-Wschodniej w XIII wieku.” W Franciszkanie w Polsce średniowiecznej, cz. 2-3: Franciszkanie na ziemiach polskich, redakcja Jerzy Kłoczowski, s. 227-248. Kraków: Prowincjałat OO. Franciszkanów Konwentualnych Prowincji św. Antoniego i bł. Jakuba Strepy, 1989.

Herrmann, Christofer. "Deutschordensland Preussen." W Mittelalterliche Architektur in Polen, redakcja Christofer Herrmann, Dethard von Winterfeld, t. 2, 858-1039. Petersberg: Michael Imhof, 2015.

Herrmann, Christofer. Mittelalterliche Architektur im Preussenland: Untersuchungen zur Frage der Kunstlandschaft und -geographie. Petersberg: Michael Imhof, 2007.

Jędrysik, Miłada. “Dwór bractwa św. Jerzego w Gdańsku.” Porta Aurea 1 (1992): 233-250.

Komorowski, Waldemar. "Gotyk w architekturze Małopolski XVI wieku. Artykuł przeglądowy." W Historyzm. Tradycjonalizm. Archaizacja: Studia z dziejów świadomości historycznej w średniowieczu i czasach nowożytnych, redakcja Marek Walczak, 177-217. Kraków: Wydawnictwo Towarzystwo Naukowe "Societas Vistulana", 2015.

Kornecki, Marian. "Dzieje sztuki regionu bocheńskiego.” W Bochnia: Dzieje miasta i regionu, redakcja Feliks Kiryk, Zygmunt Ruta, 200-228. Kraków: Urząd Miasta Bochni, 1980.

Kornecki, Marian. "Błogosławiona Kinga - pamiątki, obiekty kultu, dzieła sztuki. Inwentarz z terenu diecezji tarnowskiej." Currenda 140, nr 1-3 (1990): 87-129.

Kornecki, Marian, i Helena Małkiewiczówna. "Małopolska." W Gotyckie malarstwo ścienne $w$ Polsce, redakcja Jerzy Domosławski et al., 13-77. Poznań: Wydawnictwo Naukowe Uniwersytetu im. Adama Mickiewicza, 1984.

Kowalski, Jacek. "Pomiędzy Pomorzem, a Wielkopolską - gotycka architektura bydgoskiej katedry." W Kościół katedralny w Bydgoszczy, redakcja Aleksander Jankowski, Dariusz Karczewski, 23-52. Bydgoszcz: Wydawnictwo Uniwersytetu Kazimierza Wielkiego, 2018.

Krasnowolski, Bogusław. "Krakowskie warsztaty budowlane i kamieniarskie na przełomie średniowiecza i nowożytności." Rocznik Krakowski 72 (2006): 87-112.

Krasnowolski, Bogusław. Lokacyjne uktady urbanistyczne na obszarze ziemi krakowskiej w XIII i XIV wieku. Kraków: Wydawnictwo Naukowe Akademii Pedagogicznej, 2004.

Krasnowolski, Bogusław, i Zbigniew Beiersdorf. "Lokacja miasta i wójtostwa (1253). Próba nowej interpretacji lokacyjnego układu urbanistycznego." W Atlas historyczny miast polskich, redakcja Roman Czaja, t. 5: Małopolska, redakcja Zdzisław Noga, z. 4: Bochnia, redakcja Zdzisław Noga, 6-8. Toruń: Wydawnictwo Naukowe Uniwersytetu Mikołaja Kopernika; Kraków: Uniwersytet Pedagogiczny, 2016.

Krasnowolski, Bogusław. "W dobie odbudowy Królestwa Polskiego (1320-1380)." W Atlas historyczny miast polskich, redakcja Roman Czaja, t. 5: Małopolska, redakcja Zdzisław Noga, z. 4: Bochnia, redakcja Zdzisław Noga, 8-9. Toruń: Wydawnictwo Naukowe Uniwersytetu Mikołaja Kopernika; Kraków: Uniwersytet Pedagogiczny, 2016.

Krasnowolski, Bogusław. "Rozkwit miasta: przekształcenia centrum. Rozwój przedmieść (XV w. - pierwsza połowa XVII w.)." W Atlas historyczny miast polskich, redakcja Roman Czaja, t. 5: 
Małopolska, redakcja Zdzisław Noga, z. 4: Bochnia, redakcja Zdzisław Noga, 9-10. Toruń: Wydawnictwo Naukowe Uniwersytetu Mikołaja Kopernika; Kraków: Uniwersytet Pedagogiczny, 2016.

Kunkel, Robert M. "Fundacje Aleksandra Jagiellończyka w Wilnie i Krakowie.” W Sztuka około 1500: Materiaty Sesji Stowarzyszenia Historyków Sztuki, Gdańsk 1996, 129-143. Warszawa: ARX Regia Ośrodek Wydawniczy Zamku Królewskiego, Stowarzyszenie Historyków Sztuki, 1997.

Líbal, Dobroslav. Gotická architektura v Čechách a na Moravě. Praha: Umělecká beseda, 1948.

Pencakowski, Paweł. "Kiedy powstał gotycki korpus bazylikowy kościoła Mariackiego w Krakowie i kto go budowat?" W Magistro et Amico amici discipulique: Lechowi Kalinowskiemu w osiemdziesięciolecie urodzin, redakcja Jerzy Gadomski et al., 245-255. Kraków: Wydawnictwo Uniwersytetu Jagiellońskiego, 2002.

Pilecka, Elżbieta. "Verbindungen zwischen der spätgotischen Architektur in Danzig und Mitteldeutschland." W Mittelalterliche Architektur und Bildende Kunst im Ostseeraum. SpezifikRezeption - Restaurierung, redakcja Artur Bethke, 46-50. Greifswald: Ernst-Moritz-Arndt-Universität 1987.

Prix, Dalibor. "Związki śląsko-czeskie w architekturze średniowiecznej w okresie panowania Luksemburgów." W Ślask. Perła w koronie czeskiej. Historia, kultura, sztuka, Akademia Rycerska, Legnica, Valdštejská jízdárna, Praga, redakcja Mateusz Kapustka et al., 149-172. Praha: Národní Galerie; Legnica: Muzeum Miedzi, 2007.

Radovi, Milada, i Oldřich Radovi. Kniha o sklipkových klenbách. Praha: Jalna, 1998.

Schenkluhn, Wolfgang. Architektur der Bettelorden: Die Baukunst der Dominikaner und Franziskaner in Europa. Darmstadt: Wissenschaftliche Buchgesellschaft, 2000.

Szczepański, Jakub. "Prezbiterium kościoła franciszkanów w Gdańsku i jego lektoria.” Kwartalnik Architektury i Urbanistyki 18, nr 2 (1993): 109-118.

Tintelnot, Hans. Die mittelalterliche Baukunst Schlesiens. Kitzingen: Holzner-Verlag, 1951.

Walczak, Marek. "Bitwa grunwaldzka a sztuka od wieku XV do końca XVIII." W Na znak świetnego zwycięstwa, t. 1: Studia, redakcja Dariusz Nowacki, 269-302. Kraków: Zamek Królewski na Wawelu, 2010.

Walczak, Marek. "Działalność fundacyjna biskupa krakowskiego, kardynała Zbigniewa Oleśnickiego." Foliae Historiae Artium 28 (1992): 57-73.

Walczak, Marek. "Z najnowszych odkryć gotyckiego malarstwa ściennego (prezbiterium katedry w Sandomierzu i kościół parafialny w Lubecku).” W Imagines pictae: Studia nad malarstwem gotyckim w Polsce, redakcja Wojciech Walanus, Marek Walczak, 187-207. Kraków: Wydawnictwo Towarzystwo Naukowe "Societas Vistulana", 2016.

Węcławowicz, Tomasz. Gotyckie bazyliki Krakowa: "czyli można konstrukcję kościołów krakowskich XIV wieku uważać za cechę specjalnq ostrołuku w Polsce?”. Kraków: Wydawnictwo Wawelskie, 1993. 
Węcławowicz, Tomasz. "Małopolska i ziemie ruskie Korony." W Architektura gotycka w Polsce, redakcja Teresa Mroczko, Marian Arszyński, t. 1, 61-81. Warszawa: Instytut Sztuki PAN, 1995.

Węcławowicz, Tomasz, I Małgorzata Pietrzykówna. "Maswerki w kościołach Małopolski.”, Rocznik Krakowski 55 (1989): 45-74.

Włodarek, Andrzej. "The Gothic Church of the Benedectines' Abbey at Tyniec." Biuletyn Historii Sztuki 64, nr 1-4 (2002): 33-55.

Wojciechowski, Teofil. Kościelne dzieje Bochni 1772-1985. Bochnia, 2013.

Wojciechowski, Teofil. Kościelne dzieje Bochni w czasach staropolskich. Tuchów, 2003.

Wójtowicz, Stanisław. Kościót parafialny w Bochni i jego środowisko artystyczne. Przewodnik. Bochnia, 1983.

Wyczesany, Jerzy. Wystrój artystyczny kościoła św. Mikołaja w Bochni. Bochnia: Muzeum im. Stanisława Fischera, 1988. 